\title{
Do Risk Disclosures Matter When It Counts? Evidence from the Swiss Franc Shock ${ }^{*}$
}

\author{
Luzi Hail \\ University of Pennsylvania, The Wharton School \\ Maximilian Muhn \\ University of Chicago, Booth School of Business \\ David Oesch \\ University of Zurich
}

October 2020

\begin{abstract}
We examine the relation between disclosure quality and information asymmetry among market participants following an exogenous shock to macroeconomic risk. In 2015 the Swiss National Bank abruptly announced that it would abandon the longstanding minimum euro-Swiss franc exchange rate. We find evidence suggesting that firms with more transparent disclosures regarding their foreign exchange risk exposure ex ante exhibit significantly lower information asymmetry ex post. The information gap in bid-ask spreads appears within 30 minutes of the announcement and persists for two weeks, during which new information gradually substitutes for past disclosures. We validate the information dynamics of past risk disclosures with three field surveys: (1) Sellside analysts emphasize the importance of existing (risk) disclosures in evaluating the translational and transactional effects of the currency shock. (2) Lending banks' credit officers rely on past disclosures as the primary information source available for smaller (unlisted) firms in the immediate aftermath of the shock. (3) Investor-relations managers use existing financial filings as a key resource when communicating with external stakeholders. The results suggest that historical disclosures help investors attenuate information asymmetry in light of unexpected news.
\end{abstract}

JEL codes: F31; G12; G14; G15; G30; M41

Keywords: risk disclosures; adverse selection; liquidity; information asymmetry; information dynamics; currency risk; archival studies; surveys

\footnotetext{
* Accepted by Regina Wittenberg Moerman. We appreciate the helpful comments of an anonymous referee, Ray Ball, Phil Berger, Jeremy Bertomeu, Siddharth Bhambhwani, Matthias Breuer, Donal Byard, Vedran Capkun, Ted Christensen, Holger Daske, Peter Fiechter, John Gallemore, Joachim Gassen, Christian Hofmann, Christoph Kaserer, Christian Leuz, Miao Liu, Tim Martens, Maximilian Müller, Martin Nienhaus, Zoltán Novotny-Farkas, Natalia Reisel, Thorsten Sellhorn, and workshop participants at the 2017 American Accounting Association meeting, 2018 Swiss Winter Accounting Conference, 2018 University of Minnesota Conference, 2018 Verein für Socialpolitik Accounting Section meeting, 2018 European Accounting Association meeting, 2018 European Financial Management Association meeting, 2019 Lisbon Accounting Conference, 2019 Global Issues in Accounting Conference, Baruch College, University of Chicago, University of Hong Kong, Hong Kong University of Science and Technology, Humboldt University of Berlin, University of Illinois at Chicago, Ludwig Maximilian University of Munich, Stockholm School of Economics, and WHU. We thank Conrad Meyer and Michèle Schnyder for their help in putting us in touch with the right people for our interviews and surveys. Maximilian Muhn gratefully acknowledges the support by the German Research Foundation through the Collaborative Research Center 649 "Economic Risk" at the Humboldt University of Berlin. An online appendix to this paper can be downloaded at http://research.chicagobooth.edu/arc/journal-of-accountingresearch/online-supplements.
} 
"The Swiss franc rocketed beyond parity with the euro on Thursday after Switzerland's central bank stunned markets by scrapping its long-standing cap on the strength of the currency. The euro dropped around 30\% against the franc, ending more than three years of calm in Swiss foreign-exchange markets." Wall Street Journal, January 15, 2015.

\section{Introduction}

How do market participants cope with unexpected events that affect a firm's prospects, and what role does historical financial statement information play in this process? In standard economic theory, when new information arrives, it is immediately processed by economic agents and affects their behavior. In financial markets, when a firm releases its financial reports, new information about future expected cash flows enters the public domain, and is quickly reflected in stock prices, liquidity, and investors' trading patterns (e.g., Beaver [1968], Balakrishnan et al. [2014], Rogers et al. [2017]). However, the informational value of past disclosures does not stop there. More recent work by Linsmeier et al. [2002], Drake et al. [2016], or Choi et al. [2019] provides evidence that investors access and use financial disclosures well after their initial release.

We exploit an exogenous shock to macroeconomic risk to examine how the precision (or quality) of past currency risk disclosures is related to today's information asymmetry among market participants (in the sense of Verrecchia [2001]). We show that the market reacts to the exogenous shock in a way consistent with more precise past disclosures allowing investors to better process and interpret new information. This information disparity between firms with more and less transparent historical reporting appears almost instantaneously and lasts for about two weeks, during which newly generated information about the event gradually substitutes for past disclosures. We confirm the information dynamics of past disclosures by surveying financial analysts, credit officers in lending banks, and investor-relations (IR) managers at affected firms. 
On January 15, 2015, at 10:30 am, the Swiss National Bank (SNB) announced it would abandon the minimum exchange rate of 1.20 Swiss franc (CHF) per euro (EUR) without further notice. The SNB introduced the exchange-rate peg in September 2011 to counter the ongoing pressure on the Swiss franc to act as a "safe haven" amid the turmoil in global financial markets. The announcement to unpeg the Swiss franc caught the market by surprise and had an immediate and large impact: the EUR-CHF exchange rate dropped close to parity and Swiss stock markets lost almost $10 \%$ on a single day. See figure 1 for illustration.

The SNB announcement offers several neat features to analyze the information dynamics of past risk disclosures. First, the unpegging of the Swiss franc represents an exogenous shock, whose timing is not predictable by market participants and not influenced by either firms or investors. Second, the steep drop in exchange rates is economically significant and affects the expected cash flows of many Swiss firms because they heavily rely on exports of goods and services. Yet, the effect is not uniform but reflects a firm's business model and exposure to the euro. This private information is inherently difficult to observe and requires disclosures by the firm. Third, the initial market reaction occurs within minutes of the event, which is too short a time span for the firm to prepare and release new disclosures, so external stakeholders must rely on existing financial information, at least, in the short-term. Fourth, while firm disclosure is typically the result of an endogenous choice complicating our ability to measure the link between disclosure quality and information asymmetry (e.g., Clinch and Verrecchia [2015]), the sudden nature of the event allows us to treat disclosure quality as given in the short run. Thus, we believe that in our setting variation in the precision of a firm's past disclosures about the currency exposure of its business offers a plausible path to explain variation in the market reaction to the SNB announcement. Finally, the focus on a narrow topic like currency risk allows us to isolate the relevant portions of historical 
annual reports as well as identify new and competing information generated after the event that could substitute for past disclosures.

To test our research question, we develop a framework along the lines of Shroff et al. [2017] that posits the appearance of an information gap between firms with more and less transparent past disclosures upon the arrival of the unexpected news. We predict the informational value of past disclosures to be highest immediately following the event but then to decline and eventually dissipate as new and more up-to-date information takes its place. We test these predictions in an archival event study of changes in information asymmetry following the Swiss franc shock. For each of our 151 sample firms listed on the SIX Swiss Exchange (equal to 98\% of market capitalization), we construct a risk disclosure score. The score captures the quality of a firm's foreign exchange risk disclosures (not the actual risk exposure) based on seven disclosure items.

We find that in the initial three days after the SNB announcement uncertainty among investors dramatically increases. Bid-ask spreads, on average, jump by 21 basis points or $44 \%$ relative to the 30-day period leading up to the event. But systematic heterogeneity exists. Firms with a better risk disclosure score by one standard deviation experience less of an increase in bid-ask spreads by about 7 basis points. These base results are robust to the inclusion of firm and industry-by-day fixed effects and extend to other measures like return variability or effective spreads. They also hold when we control for a firm's general information environment, actual currency risk exposure, quality of risk management, hedging activities, or direct communication with investors.

We then refine our tests along the predictions from our framework. An analysis of intraday spreads reveals that the information gap between more and less transparent firms appears within 30 minutes of the SNB announcement. This reaction is simply too quick for firms and analysts to release new information or engage in private communication. When we extend the event window, 
we find that the information gap is largest immediately following the event but then starts to decline until it disappears after ten trading days. Using data on analyst forecast revisions and relevant newspaper articles (which both substantially increase in the days following the event), we find that this newly generated information itself reduces information asymmetry and, by doing so, gradually substitutes for the information content of past risk disclosures. Finally, in an attempt to validate our empirical strategy, we find that a firm's currency risk exposure (but not its risk disclosure score) is negatively related to stock prices following the Swiss franc shock.

In the second part of the study, we collect field data from various financial statement users: (i) sell-side analysts, (ii) credit officers of lending banks, and (iii) IR managers at firms listed on SIX. Based on 77 survey answers (9.4\% response rate), financial analysts indicate that they were surprised by the SNB move and expected major ramifications for their portfolio firms. More to the point, they respond that existing annual reports served as a key information resource in the immediate aftermath of the event, on par with private communication with management, and ranked only behind analysts' personal experience and industry knowledge. This role declined in the days that followed, as ad hoc announcements gained importance. The main use of financial statement information was to better contextualize and interpret the translational and transactional currency risk exposure and to assess the effectiveness of firms' hedging strategy.

In a series of structured interviews, credit officers from four large Swiss banks indicated that within a week after the SNB announcement (two to four weeks for private clients), lending banks reviewed their entire loan portfolios and classified firms into different risk categories. The main, and for non-listed firms only, information source for this initial review were existing financial documents submitted during the periodic loan review. 
Based on 39 survey replies by IR managers ( $26 \%$ response rate), we find that close to $50 \%$ of the firms started communicating with external stakeholders on the day of the event, primarily through private channels with financial analysts and institutional investors. The main goals were to reassure investors, reduce uncertainty, and build trust in the firm's reporting strategy. Past annual reports served as important information source for the IR managers. When we integrate select survey responses into the archival tests, we find that, while being negatively related to bidask spreads itself, direct communication with external stakeholders does not fully subsume the information content of past risk disclosures in the days immediately following the event.

We see the contribution of our study as threefold. First, we extend prior literature on the usefulness of past financial statement information. While prior studies find evidence of investors accessing historical accounting reports in times of general uncertainty (Drake et al. [2016]) or show a persistent reduction in the sensitivity of daily trading volume to macroeconomic changes after the mandated disclosure of market risks (Linsmeier et al. [2002]), we take a more nuanced approach. We analyze a single historical disclosure topic (currency risk) and how it relates to market reactions in a narrow window (30 minutes to 20 trading days) around a unique but highly relevant event (change in currency regime). This focus allows us to open the black box of how past disclosures provide a channel through which they affect information asymmetry. It also lets us test several dynamic aspects of the information content of past disclosures. It turns out that, while they materialize almost instantaneously, the informational benefits last only for about two weeks and newly generated information quickly takes their place. Yet, the benefits come at a crucial time when uncertainty and divergence in opinion in the marketplace are arguably highest.

Second, we contribute to the literature on the link between disclosure and information asymmetry which is well-founded in theory (e.g., Diamond and Verrecchia [1991], Verrecchia 
[2001], Goldstein and Yang [2017]). We find that the precision of past risk disclosures explains systematic variation in information asymmetry well beyond the initial publication date. Put differently, disclosures not only have the ability to mitigate adverse selection upon release (e.g., Brown et al. [2009], Shroff et al. [2013], Balakrishnan et al. [2014]), but also in the future. Our channel is different from credibly committing to future transparent reporting (Leuz and Verrecchia [2000], Francis et al. [2008], Daske et al. [2013]) or from changing (voluntary) disclosures in response to a fundamental shock (e.g., Leuz and Schrand [2009], Balakrishnan et al. [2014]). The effect in our setting is transitory and relies on holding the quality of past disclosures constant. Although we do not claim causality, the exogenous event combined with a fast market response offer identification benefits (similar to Balakrishnan et al. [2014]). Moreover, by complementing archival with survey methods (e.g., Soltes [2014], Bernstein et al. [2016]), we draw a richer picture of how not only investors, but also analysts, lenders, and IR managers rely on historical accounting reports, increasing our confidence in the stipulated relation.

Finally, our study contributes to the literature on corporate risk disclosures. Prior studies examine the stock market reaction to risk disclosures (e.g., Campbell et al. [2014], Heinle and Smith [2017]), assess firms' ability to predict future risk (e.g., Jorion [2002]), or investigate incentives for strategic risk reporting (e.g., Begley et al. [2017]). We test whether risk disclosures help market participants gauge the impact of a sudden realization of risk.

\section{Related Literature, Hypothesis Development, and Institutional Setting \\ 2.1. RELATED LITERATURE}

We analyze the informational role of past risk disclosures. Most archival research has focused on the information content of newly released disclosures; that is, whether the information contained 
in these disclosures changes investors' beliefs about future returns or prices (e.g., Beaver [1968]). In this context, the new information signal transfers previously unknown or private information into the public domain and the release of the information and the market reaction occur almost instantaneously. More recent work extends this view and separates the release of the information from the market reaction that occurs later when macroeconomic or firm conditions change.

Most prominently, Drake et al. [2016] focus on investors' search behavior of the SEC EDGAR database in light of significant firm events like negative shocks to earnings or value and find substantive spikes in daily requests of historical accounting reports. Linsmeier et al. [2002] exploit firms' risk disclosures and show that following the mandated disclosure of market risk exposure, investors are better able to process future changes in the underlying interest rates, exchange rates or commodity prices, leading to less uncertainty and diversity in opinion. Choi et al. [2019] show that firms with previous management guidance experience significantly lower implied volatility around the subsequent release of the Federal funds rate target. More generically, Lang and Maffett [2011] find that greater firm-level transparency is related to less liquidity volatility and fewer extreme illiquidity events, in particular during times of crisis when investor uncertainty is high. All these studies have in common that they tie some notion of past disclosures to current investor behavior upon the arrival of a new public signal.

Our analysis is also related to prior studies that focus on the signaling effect of past disclosures (e.g., Blacconiere and Patten [1994], Banker et al. [1995], Heflin and Wallace [2017]). In these studies, the past public announcement proxies for the actual risk exposure of the firms and, hence, it should be related to the price reaction upon the change in risk. We instead focus on how transparency with regard to firms' risk exposure relates to the transaction costs that arise from the 
adverse selection problem between investors when interacting with each other. ${ }^{1}$ In terms of identification, our study is related to Blacconiere and Patten [1994], Bonetti et al. [2018] and Cuny and Dube [2019] who also use exogenous disasters or events to observe market behaviors conditional on extant disclosures. However, they focus on the short-term price reactions and the effects on long-term cost of capital or debt ratings, respectively, which is different from the purely information-driven mechanism at work in our setting. Finally, our study fits into the general body of work on the link between disclosure quality and information asymmetry among market participants (e.g., Leuz and Verrecchia [2000], Daske et al. [2008], Balakrishnan et al. [2014]).

\subsection{CONCEPTUAL UNDERPINNINGS FOR THE INFORMATIONAL VALUE OF PAST}

\section{RISK DISCLOSURES}

We build on the above stream of literature — in particular on Drake et al. [2016] and Linsmeier et al. [2002] — and extend it by examining two distinct features of how the precision (or quality) of past public announcements complements current public information signals: (i) the emergence of an information gap and (ii) the persistence of the information gap amid newly generated information. Figure 2 illustrates our hypothesis development. First, the Swiss franc shock allows us to open the black box in Drake et al. [2016] and zoom in on a specific channel that transforms historical annual report information into a reaction by market participants. The arrival of unexpected news about the state of the firm increases uncertainty among investors. As market participants scramble to assess the economic consequences of the event, past disclosures about how the firm handles currency risk help investors contextualize and interpret the new situation and

\footnotetext{
1 This focus on information asymmetry is the reason why we use bid-ask spreads as the dependent variable in our tests and not price. At the same time, we are not arguing that the overall market reaction to the Swiss franc shock was not large and unlikely to be a function of a firm's exposure to the euro. It was, and from a price perspective, this market reaction certainly must be considered the first-order effect of the Swiss franc shock (see also section 3.5).
} 
reduce some of the uncertainty. As the figure shows, firms $i$ and $j$ differ in the quality of past risk disclosures (which were released in last year's annual report). The sudden nature of the shock allows us to treat this difference as given in the very short-term because firms simply have no time to adjust their past risk disclosures or supplant them with new information. We expect firms with more precise past risk disclosures to suffer less of an increase in information asymmetry upon the SNB announcement as predicted by theory (e.g., Diamond and Verrecchia [1991], Verrecchia [2001], Goldstein and Yang [2017]). As a result, an information gap appears. ${ }^{2}$

Second, in line with Shroff et al. [2017], who examine the role of (past) peer information, we investigate the dynamic nature of the information gap. Figure 2 shows that following the SNB announcement, new event-specific information regarding firm $i$ or $j$ is generated, be it through firm disclosures (e.g., ad hoc announcements, press releases), analyst reports (e.g., forecast revisions), news articles in the media, etc. We expect the supply of (and demand for) new information to be highest in the early days after the event, but then to gradually decrease over time. As a result, the information advantage for investors in firm $i$ relative to investors in firm $j$ is transitory and disappears over time as the amount of new information increases. Eventually, the information gap closes (when the new information curve crosses the past risk disclosures line for firm $i$ ) and only the new information continues to affect information asymmetry. As to the duration of the information gap, we do not have a clear prediction but expect it to be rather short (days or weeks) in light of the potential impact of the information shock on firm fundamentals.

${ }^{2}$ Our setting is related to Kim and Verrecchia [1994, 1997]. In their models, past private information interacts with a new public signal, thereby exacerbating the informational disadvantage of the uninformed investors. We would obtain the same prediction if sophisticated investors saw more value in acquiring additional private information for low-quality disclosure firms upon the arrival of the sudden news (i.e., high-quality risk disclosures crowd out private information acquisition by sophisticated investors). 


\subsection{INSTITUTIONAL SETTING OF THE SWISS FRANC SHOCK}

The Swiss franc has a long tradition of acting as a safe-haven currency for investors when global financial markets are in turmoil. On September 6, 2011, the SNB declared that it would set a currency floor of CHF 1.20 per EUR as a reaction to deflationary pressure. The SNB insisted that it was committed "to buy foreign currency in unlimited quantities" (SNB [2011]). In the years that followed, the Swiss franc was effectively pegged against the euro. On January 15, at exactly 10.30 am local time, the SNB released an official statement declaring that it would abandon the minimum EUR-CHF exchange rate without further notice (SNB [2015]). ${ }^{3}$ The sudden policy change came as a surprise to market participants. For instance, Bloomberg News [2015] had surveyed 22 economists in the first two weeks of 2015 and none of them expected that the cap would be abandoned in 2015. A Deloitte [2015] survey conducted in December 2014 found that only 3 out of 129 chief financial officers of Swiss firms expected a change in the currency regime in $2015 .{ }^{4}$ As figure 1 indicates, the market reaction was swift, and the Swiss franc immediately soared against the euro. At closing, the Swiss franc had risen against the euro (U.S. dollar) by $14 \%$ (12\%). The Swiss All Share index (SSIP) dropped by almost 9\%. Efing et al. [2020] find that the negative wealth effects of the Swiss franc shock were stronger for export-oriented firms with a heavy reliance on domestic production.

${ }^{3}$ In the same statement, the SNB also announced to lower deposit interest rates. Unlike the minimum exchange rate decision, analysts had expected to see lower deposit rates in the near future.

${ }^{4}$ The SNB announcement was also not part of the ongoing monetary policy assessments that the bank conducts at preset dates every three months. At the previous meeting in December 2014, the press release under the headline "Swiss National Bank reaffirms minimum exchange rate" stated that "the SNB will continue to enforce the minimum exchange rate with the utmost determination" (SNB [2014]). The next meeting was scheduled for March 2015. 


\section{Archival Analysis of Past Risk Disclosures and Information Asymmetry}

\subsection{RESEARCH DESIGN}

To test the informational role of past risk disclosures as outlined in section 2.2, we examine changes in daily bid-ask spreads around the Swiss franc shock conditional on the quality of a firm's risk disclosures. We estimate the following ordinary least squares (OLS) regression model:

$$
\begin{aligned}
& \log \left(\text { Bid-Ask Spread }_{i, t}\right)= \beta_{1} \text { Post_SNB }_{t}+\beta_{2} \text { Post_SNB }_{t} \times \text { FXRisk_Disc }_{i}+\sum \beta_{j} \text { Controls }_{i, t-1}+ \\
& \sum \beta_{k} \text { Post_SNB } B_{t} \times \text { Controls } i \\
&+\sum \beta_{l} \text { Fixed Effects } i_{i, t}+\varepsilon_{i, t .}
\end{aligned}
$$

The dependent variable, Bid-Ask Spread, is the mean of intraday minute-by-minute differences between bid and ask quotes (divided by the mid-point) for firm $i$ on trading day $t$. Post_SNB is a binary indicator that takes on the value of ' 1 ' beginning on day $t=0$ of the SNB announcement (January 15, 2015), and ' 0 ' beforehand. The sample period comprises the 33 trading days around the SNB announcement, with $t \in[0 ;+2]$ serving as event window and $t \in[-30 ;-1]$ as benchmark period. Post_SNB captures the mean incremental change in bid-ask spreads following the event. We predict that this coefficient is positive, indicating a sudden increase in information asymmetry regarding future EUR-CHF exchange rate fluctuations.

The primary test variable, FXRisk_Disc, is a proxy for the quality of foreign exchange risk disclosures of firm $i$ as reported in the most recent annual report before the event (i.e., for fiscal year 2013). ${ }^{5}$ We rely on annual reports because they represent by far the most comprehensive source for currency risk information. ${ }^{6}$ We construct FXRisk_Disc by scoring seven items: (i)

${ }^{5}$ Over $90 \%$ of the sample firms end their fiscal year on December 31 and publish the annual report within two to four months. Most of the remaining firms have fiscal year ends of March 31. Thus, none of the sample firms had released its 2014 annual report at the time of the SNB announcement.

${ }^{6}$ We checked a random sample of quarterly and half-year reports as well as other financial filings occurring over the course of the fiscal year but could not identify additional relevant risk information in those interim disclosures. 
revenues, (ii) assets, and (iii) costs/profits generated and held outside of Switzerland; (iv) the currency distribution of short-term monetary assets and liabilities; (v) the exposure to and (vi) the hedging strategy regarding foreign currency risk; and (vii) the sensitivity of net income or shareholders' equity to changes in foreign exchange rates. Each disclosure item receives a score of 1 (quantitative and qualitative information), 0.5 (qualitative information), or 0 points (no or boilerplate disclosures), and the variable FXRisk_Disc equals the sum of points, ranging from 0 (worst) to 7 (best). For ease of interpretation, we standardize the raw scores to a mean of zero and a standard deviation of one for use in the regression analysis. In part A of the online appendix, we provide details on the construction of this variable together with illustrative examples.

The idea underlying FXRisk_Disc is to gauge the quality of the information, not the actual risk exposure of the firm. We expect the interaction term between Post_SNB and FXRisk_Disc to be negative, indicative of the information gap in figure 2. Because we include firm fixed effects, the main effect of FXRisk_Disc (as well as any intercept) does not appear in equation (1). When we control for daily trends in the data, the day fixed effects subsume the main effect of Post_SNB, and the interaction term is specified by the within-day, between-firm variation in bid-ask spreads.

In terms of firm-level Control Variables, we follow prior research (Chordia et al. [2000], Leuz and Verrecchia [2000], Christensen et al. [2013]), and include the Market Value of equity at the end of each trading day, daily Share Turnover, and Return Variability equal to the standard deviation of half-hourly stock returns over the trading hours of the day. Depending on the model, we include a vector of additional control variables and interact them with Post_SNB to allow the event effects to vary across firm attributes. Because most of these attributes are time-invariant, the firm fixed effects subsume the respective main effects. The model comprises firm, day, or onedigit SIC industry-by-day Fixed Effects to account for the mean bid-ask spread along these 
dimensions. We partial out the fixed effects when computing the adjusted $\mathrm{R}^{2}$ and report "within" adjusted $\mathrm{R}^{2}$ values in the tables. We estimate equation (1) in a log-linear form using the natural logarithm of bid-ask spreads and the time-varying control variables (lagged by one day). ${ }^{7} \mathrm{We}$ draw statistical inferences based on two-way clustered standard errors by firm and trading day.

\subsection{SAMPLE SELECTION AND DESCRIPTION}

The initial sample comprises 237 publicly traded firms with a primary listing in Switzerland that are constituents of the SSIP at the end of 2014. We collect minute-by-minute intraday spread data from Bloomberg. For each firm-minute, Bloomberg reports bid and ask quotes, trade prices, CHF volumes, and the number of ticks. To avoid potential market microstructure biases such as the stale quotation problem (McInish and Wood [1992]), we apply a series of data filters to obtain the final sample as outlined in table 1, panel A. We require firms to have, on average, at least ten trades per day and updated daily bid-ask spreads on at least 141 out of the 144 trading days ( $\geq 97.5 \%$ ) over the October 2014 to April 2015 period. These two criteria eliminate thinly traded firms and firms with narrow market depth. We also delete firms with missing data for the variables used in the regression analysis. The selection procedure yields a final sample of 151 firms.

We further restrict the spread data to trading hours (i.e., 9.00 am to $5.30 \mathrm{pm}$ ), and delete bid and ask quotes with zero value or volume ( $\mathrm{Ng}$ et al. [2008]). ${ }^{8}$ We replace missing quotes (i.e., no new bid or ask quotes during a specific minute) by carrying the previous quotes forward within a day, but not across days (McInish and Wood [1992]). We obtain daily data by taking the mean of minute-by-minute spreads, but do not consider negative spreads (McInish and Wood [1992], Chan

7 The computation of the control variables for the last two days of the three-day event window is potentially tainted by the SNB announcement. However, when we lag the time-varying control variables by five trading days (instead of one) or use the values from day [-1] throughout the event period, the results are very similar to those reported.

${ }^{8}$ SIX randomly opens trading between 9.00 and 9.02 am (opening auction), and no trades are settled between 5.20 and $5.30 \mathrm{pm}$ (closing auction). Thus, we only consider quotes between 9.02 am and $5.20 \mathrm{pm}$. 
et al. [1995]). ${ }^{9}$ We use the most recent transaction prices when computing half-hourly log returns for the return variability measure.

Panel B of table 1 provides descriptive statistics for the variables used in the daily bid-ask spread regressions. The mean Bid-Ask Spread is 48 basis points, which is smaller than the values reported for broader samples (e.g., Christensen et al. [2016]), and consistent with our firms being highly traded and liquid. The mean and median values of the FXRisk_Disc score are 4 points out of 7. The interquartile range of 2 points suggests ample variation. We do not assume that a firm's risk disclosure quality is random. In an exploratory analysis, we find that general accounting quality and the reporting standards followed are important determinants of FXRisk_Disc. These results are not surprising as risk disclosures are part of a firm's overall disclosure strategy and international accounting standards like IFRS or U.S. GAAP prescribe more extensive risk disclosures than local GAAP. Other factors such as the quality of risk management or the actual currency risk exposure seem unrelated to FXRisk_Disc. ${ }^{10} \mathrm{We}$ deal with this endogeneity by including explicit controls for potentially correlated factors. In addition, the sudden nature of the Swiss franc shock allows us to treat the quality of past risk disclosures as given in the short-term.

Panel B also tabulates descriptive statistics for the other variables that we use in the analyses. For details on the variable definitions, see the notes to table 1 . We do not winsorize or truncate any of the data. ${ }^{11}$ The median sample firm is covered by four analysts, has a free float of $69 \%$, and a market capitalization of CHF 1.26 bn. Thus, these firms are large and visible. On average, firms generate two thirds of their sales outside of Switzerland, suggesting a heavy reliance on exports

\footnotetext{
${ }^{9}$ In robustness tests (not tabulated), we account for stale quotes by removing the $5 \%$ of daily observations with the highest staleness (i.e., average difference between bid and ask quotes of more than 34 minutes). The results remain largely unaffected by this adjustment.

${ }^{10}$ We provide details on the determinants analysis and tabulate results in section B.3 of the online appendix.

${ }^{11}$ When we winsorize or truncate all the continuous variables in equation (1) at the first and $99^{\text {th }}$ percentile, the results remain largely unaffected and none of the inferences change (see section B.2.5 of the online appendix).
} 
and a potentially substantive exposure to risks from foreign currency fluctuations. Both our measures of currency risk exposure (Int_Sales and Hist_Corr_EUR) display ample variation, suggesting that the effect of the Swiss franc shock differs across firms.

\subsection{CHANGES IN INFORMATION ASYMMETRY AROUND SWISS FRANC SHOCK}

3.3.1. Graphical Analysis of Daily Bid-Ask Spreads. We begin the archival analyses with plotting the mean daily bid-ask spreads over the 90 trading days surrounding the event (i.e., days $[-70 ;+20])$ and report results in figure 3 . The solid line represents firms with high-quality past risk disclosures (i.e., FXRisk_Disc greater than the sample median). The dashed line stands for a synthetic control group (e.g., Abadie et al. [2010]). Following Cavallo et al. [2013] and Acemoglu et al. [2016], we match each high-quality disclosure firm to a combination of all firms with an FXRisk_Disc score at or below the median (benchmark pool) using a convex weighting matrix that minimizes the Euclidean differences in the outcome variables on each trading day over the [-70;1] period. That is, we use 70 daily bid-ask spreads for the matching. In the pre-event period, the variability in spreads is already substantial, with a peak around day [-58] and a dip around day [32], but-by construction - the two groups largely move in parallel. On the day of the announcement, spreads rise dramatically and remain at higher levels for the initial days, before gravitating towards pre-announcement levels. The pattern indicates that the currency shock increases the uncertainty in the markets. More to the point, the reaction to the SNB announcement is much abated for firms with high-quality risk disclosures. Visually, the gap in spreads between the two groups persists for about 10 to 15 trading days after the event. ${ }^{12}$

\footnotetext{
${ }^{12}$ We repeat this analysis with an alternate control group that incorporates various properties of the spread and return distributions (e.g., maximum and minimum values, standard deviation) to account for the extreme nature of the event. Results are very similar and none of the inferences change (see section B.1 of the online appendix).
} 
3.3.2. OLS Regression Analyses of Daily Bid-Ask Spreads. In table 2, we report coefficients and $t$-statistics from estimating variations of equation (1). The model in column (1) contains the basic liquidity controls plus firm fixed effects. The significantly positive coefficient on Post_SNB indicates that, relative to the pre-event level, bid-ask spreads increase by 21 basis points or $44 \%$ $\left(e^{0.367}-1\right)$ after the Swiss franc shock. However, the effect is mitigated for firms with more informative past risk disclosures. The significantly negative coefficient on the interaction term between Post_SNB and FXRisk_Disc suggests that a one standard deviation increase in the risk disclosure score is associated with less of a jump in bid-ask spreads by about 7 basis points or almost a third compared to the average reaction. ${ }^{13}$ The control variables are all significant and have the predicted signs.

In column (2), we allow the effect to differ across large and small firms and add an interaction between Post_SNB and the natural logarithm of a firm's mean market value over the benchmark period (Market Value-30,-1) to the model. We further include fixed effects for each trading day, which flexibly control for trends in the data and subsume the main effect of Post_SNB. In column (3), we allow for the possibility that the Swiss franc shock impacted some industries more than others and let the day fixed effects vary by one-digit SIC industry.

In column (4), we control for the mitigating effects of currency risk exposure and overall disclosure quality. Specifically, we include an operations-based proxy (IntSales) and a marketbased proxy (Hist_Corr_EUR) of a firm's actual exposure to currency risk in the model. Firms with higher exposure to exchange rate fluctuations might face higher uncertainty immediately after

\footnotetext{
${ }^{13}$ We compute the 7 basis points as $\left(e^{-0.103}-1\right)$ multiplied by the post-event mean spread ( 69 basis points). This effect roughly translates into a $10 \%$ decrease. Relative to the pre-event mean bid-ask spread, the increase is reduced by 14 percentage points computed as the difference between the full effect $(+44 \%)$ and the mitigated effect $(+30 \%$, i.e., $\left.\left[e^{0.367-0.103}-1\right]\right)$.
} 
the event. We also control for the overall quality of a firm's annual report (Total_Disc) and its information environment (Num_Analysts). Firms with transparent annual reports likely have more informative risk disclosures. Analysts are sophisticated users of firm information and often possess superior information capabilities and private communication channels with management (Brown and Rozeff [1978], Brown et al. [2015]). Finally, we control for ownership structure (Free Float). The lower the proportion of corporate insiders, the less afraid corporate outsiders should be of trading with a better-informed party.

In column (5), we add concurrent daily stock returns and its interaction with Post_SNB to the model as another way of controlling for a firm's actual risk exposure. Firms with large negative price reactions (and, hence, a higher exposure) to the currency shock likely face more uncertainties about the future. We find that, on average, contemporaneous stock returns are negatively related to bid-ask spreads. The relation is more pronounced after the event (but the difference not statistically significant). Throughout columns (2)-(5), the Post_SNB $\times$ FXRisk_Disc term is largely unaffected by the inclusion of the additional controls. In column (6), we use Return Variability as alternative proxy of information asymmetry that, among other things, captures intraday price reversals. The results are very similar.

3.3.3. Sensitivity Analyses. We conduct a series of sensitivity tests of our main analysis in table 2: (i) We control for additional potential moderators of the relation between risk disclosures and information asymmetry. Specifically, we create proxies for the quality of a firm's risk management (e.g., the existence of a chief risk officer), its hedging activities (e.g., the number of times the term "hedging" is mentioned in the annual report), and the extent of its direct communication with investors and analysts (e.g., the number of employees with the term "IR" or "investor relations" in the job title). It is plausible that firms with better risk management and 
extensive derivative or economic hedging are less affected by the Swiss franc shock. Firms with a proven track record of communicating quickly and transparently with outside stakeholders might see less of an increase in information asymmetry. We interact each proxy with Post_SNB and include it in the model.

(ii) We include two additional proxies for a firm's general disclosure quality, namely the length of the 2013 annual report (measured by the number of pages) and an indicator marking firms that follow international accounting standards (IFRS or U.S. GAAP). The interpretation of annual report length as a proxy of disclosure quality is ambiguous and could go either way. ${ }^{14}$ International standards prescribe more extensive (risk) disclosures and might proxy for a more transparent information environment. We also separately estimate the relation for firms following local GAAP (33 firms) or international standards (118 firms).

(iii) We control for the existence of a U.S. cross-listing on an exchange, in the over-thecounter markets as sponsored American depositary receipt (ADR), or through an unsponsored ADR program. U.S. cross-listed firms might be subject to more extensive risk disclosure rules and intensified public scrutiny (e.g., Doidge et al. [2004]). (iv) We add interaction terms between Post_SNB and the time-variant liquidity controls (Market Value, Share Turnover, and Return Variability) to the model. (v) We use effective spreads instead of quoted spreads as well as the intraday version of the Amihud [2002] illiquidity measure as dependent variables.

\footnotetext{
${ }^{14}$ For instance, Li [2008] interprets longer annual reports as more difficult to read. Lang and Stice-Lawrence [2015] argue that longer reports contain more information and find a positive relation with regulation and incentives for more transparent reporting. In our sample, the coefficient on the interaction term between annual report length and Post_SNB is significantly negative, consistent with lower information asymmetry (and the second interpretation).
} 
For each of these sensitivity tests, the main coefficient of interest, Post_SNB $\times$ FXRisk_Disc, is significantly negative and none of the inferences change. ${ }^{15}$ We tabulate and discuss all sensitivity tests in section B.2 of the online appendix.

\subsection{ANALYSIS OF INFORMATION DYNAMICS AROUND SWISS FRANC SHOCK}

As illustrated in figure 2, we posit that variation in the quality of past risk disclosures gives rise to an almost instantaneous information gap following the SNB announcement. The quicker the market reaction, the more difficult it becomes to attribute the effects to alternative information sources. As market participants, intermediaries and the media generate and release new information over the subsequent days, the information gap diminishes and eventually disappears. In the interim, old and new information likely interact and either reinforce or substitute for each other. In what follows, we conduct tests for each of these predictions.

3.4.1. Appearance of Information Gap-Analysis of Intraday Bid-Ask Spreads. To test for the immediacy of the information gap, we examine the trading patterns on the event day. We estimate a version of equation (1), in which we replace Post_SNB with 17 separate indicator variables for each 30-minute trading interval of the event day (i.e., from 9 am to 5:30 pm). For instance, the 11:30-12:00 Dummy represents the 30 minutes from 11:30 am to noon. We then interact these time indicators with FXRisk_Disc. The SNB announcement took place at 10:30 am. Thus, the information gap should exist from this point onward but not before. All variables are computed similarly as before, but with respect to 30 -minute instead of daily trading intervals. We assess the

\footnotetext{
${ }^{15}$ With one exception the magnitudes of the Post_SNB $\times$ FXRisk_Disc terms are very similar to those in table 2 . When estimating the models separately for local GAAP firms and firms with international standards, the coefficients of interest become more negative for the former ( -0.140 based on model 5$)$ and less negative but still significant for the latter firms (-0.032). This result is consistent with local GAAP firms having more discretion in their risk disclosure choices as well as a less transparent information environment to begin with.
} 
statistical significance based on robust standard errors with two-way clustering by firm and trading interval. Table 3, panel A, reports the results.

In column (1), we combine the day of the SNB announcement with the benchmark period (i.e., $t \in[-30 ; 0])$, and include both firm and time-of-day fixed effects. The series of interaction terms is defined by the within-trading interval, between-firm variation in spreads. The main effects of the time dummies are small and only marginally significant before 10:30 am, suggesting no abnormal activity relative to the benchmark period. Beginning with the 10:30 to 11:00 am interval, they become significantly positive. The coefficient magnitudes suggest substantive increases in bid-ask spreads ranging from $148 \%(12.30$ to $1.00 \mathrm{pm})$ to $36 \%(5.00$ to $5.30 \mathrm{pm})$. The interaction terms with FXRisk_Disc are small and insignificant before 10:30 am, but then quickly turn significantly negative from 11:00 am onwards. Within 30 minutes of the announcement, firms with better risk disclosures experience a reduced effect on information asymmetry on the order of $-19 \%$ (12.30 to $1.00 \mathrm{pm})$ to $-6 \%(3.00$ to $3.30 \mathrm{pm})$.

We repeat the analysis with event-day observations $(t=0)$ and report results in column (2). The time-of-day fixed effects subsume the main effects of the time indicator variables. ${ }^{16}$ The results are very similar. While firms with higher quality risk disclosures have no information advantage in the trading hours before the event, a significant gap in bid-ask spreads appears within minutes of the unexpected announcement and persists for the remainder of the day. ${ }^{17}$ The intraday results provide strong support for the stipulated link between the advent of fundamental news and

\footnotetext{
${ }^{16}$ We do not include firm fixed effects in this specification as they would subsume one of the interaction terms with FXRisk Disc and render the interpretation of the remaining interactions relative to this base period.

${ }^{17}$ When we use trade-size to infer whether trades were executed by retail or institutional investors (e.g., Lee [1992]), we find that the fraction of small trades $(<\mathrm{CHF} 7,500)$ significantly decreases after the event (not tabulated). This drop occurs within 30 minutes of the announcement and applies to all firms. Both analysts and IR managers confirm in their survey answers that they communicated mainly with institutional investors immediately after the event.
} 
information asymmetry through the channel of a firm's past risk disclosures. The market reaction is simply too quick for firms and financial analysts to release new information or engage in private communication at such short notice. Any longer time span for markets to react (say, four hours or a full day), would make alternative information sources more likely explanations for the findings. We note, however, that we do not interpret the 30-minute window as evidence of investors or analysts literally scrambling for past annual reports, quickly screening the information and then adjusting their behavior (even though we did receive anecdotal feedback from one analyst describing exactly such actions). Rather, we see our risk disclosure score as a proxy for better general knowledge about a firm's risk situation that is sourced in historical annual reports.

\subsubsection{Persistence of Information Gap-Analysis of 20-Day Event Window. We next examine} the duration of the information gap. Figure 2 only predicts that the informational value of past risk disclosures is transitory and that new and updated information sources (within and outside of the firm) take its place as time goes on. It does not predict for how long the information gap persists. To provide some descriptive evidence on this issue, we adjust equation (1) by extending the event window to $t \in[0 ;+20]$ and coding three separate Post_SNB $B_{t}$ indicators for $t \in[0 ;+2],[+3 ;+10]$, and $[+11 ;+20]$. We then interact each of these indicators with FXRisk_Disc. ${ }^{18}$ Panel B of table 3 reports the results. In column (1), we include the basic controls plus firm fixed effects. We therefore can estimate the Post_SNB $B_{t}$ coefficients. The increase in information asymmetry is largest in the three days following the SNB announcement, declines in the days that follow, but remains significantly positive until at least day $[+20]$.

${ }^{18}$ To keep the model simple, we do not interact Post_SNB $B_{t}$ separately with each control variable but use a single Post_SNB indicator instead. However, when we do introduce separate interactions with each control (not tabulated), the results are very similar to those reported and none of the inferences change. 
More to the point, the information gap between firms with better and worse risk disclosures is largest in the first three event-days, persists at lower levels for days $[+3 ;+10]$, and then disappears as shown by the three interaction terms (using $F$-tests, we confirm that the coefficients are significantly different from each other). Thus, the information gap persists for about 10 trading days. ${ }^{19}$ The results look very similar when we add the other controls and day or industry-day fixed effects (columns 2-5). In Colum (6), we report results for Return Variability, which displays a similar pattern but at lower levels of statistical significance.

The short-lived nature of the information gap is consistent with expectations and increases our confidence in the research design. The issue then becomes one of economic significance. We deem a mitigation of the sudden jump in information asymmetry following the SNB announcement by about $14 \%$ relative to the overall mean spread (see Footnote 13) for more transparent firms economically substantial. Compared to other settings with a persistent change in disclosure quality and/or strict enforcement of disclosure regulation, the effects that we find are smaller (as one would expect) but still large enough to matter for market participants. ${ }^{20}$ Moreover, we find that the average daily trading volume significantly increases by more than $85 \%$ over the two weeks after the SNB announcement relative to the benchmark period (not tabulated). Thus, the informational benefits of past risk disclosures come at a time with high uncertainty and divergence in opinions among market participants.

3.4.3. Substitutive Effects between Historical and New Information. In figure 2, we assume that new event-specific information increases with a positive but decreasing slope after the event.

${ }^{19}$ This time frame is consistent with the survey answers of sell-side analysts (see section 4.1 and table 4).

${ }^{20}$ For instance, Daske et al. [2008] report a $6.4 \%$ to $15.1 \%$ reduction in bid-ask spreads around mandatory IFRS adoption (see their table 4). Christensen et al. [2013] find a decrease by $17.5 \%$ to $35.1 \%$ around substantial enforcement changes of disclosure regulation in the European Union (see their table 4). Christensen et al. [2016] report a reduction of about $20 \%$ following two major changes in securities laws (see their online appendix). 
To validate this assumption, we collect two sources of news and plot the frequency of their occurrence over the $[-20 ;+20]$ day period around the SNB announcement. Specifically, we collect data on (i) newly issued revisions of analyst earnings-per-share forecasts (EPS_Revision) for firm $i$ on trading day $t$ (source: $\mathrm{I} / \mathrm{B} / \mathrm{E} / \mathrm{S}$ ), ${ }^{21}$ and (ii) newly published newspaper articles covering the impact of the Swiss franc shock for a specific firm $i$ on trading day $t$ (News). ${ }^{22}$ We plot the histogram for EPS_Revision and News in figure 4. The number of EPS forecast revisions increases drastically after the SNB announcement. In the pre-period, on average, analysts release 19 EPS revisions per day; this number increases to 66 in the post-period. The daily numbers peak in the three trading days $[+1 ;+3]$ and then start to decrease. Similarly, the print media publishes the highest number of relevant newspaper articles immediately following the event (i.e., days $[+1,+2$, and +4$])$ before the numbers gradually decline. The patterns that we find are consistent with the arrival of new event-specific information as hypothesized.

To better understand the interplay of past risk disclosures and newly generated information, we next estimate equation (1) but include a new information variable New_Info (measured either as EPS_Revision, News or the sum of the two, Combined) plus its interactions with Post_SNB and FXRisk_Disc in the model..$^{23}$ Panel C of table 3 presents the results. The interaction terms between

${ }^{21}$ We use the Thomson Reuters $I / B / E / S$ detail history file to collect analyst forecast revision data. Each forecast comes with a timestamp. We assign forecasts issued after 11:30 am EST (i.e., 5:30 pm local Swiss time) to the next trading day because they were issued after the close of trading on SIX.

22 We conduct a Factiva search of all Swiss newspaper articles (excluding newswires) that were published between January 15 and February 12, 2015 (i.e., days $[0 ;+20]$ ). For each sample firm, the search term contains (i) the company name (or its iterations) and (ii) the term "Swiss National Bank" (or its abbreviations and translations: "SNB," "BNS," "Nationalbank," "Banque Nationale") or the term "Mindestkurs" (i.e., minimal rate). This search strategy produces 1,641 articles. Two of the authors then independently read the full texts of every article and classify them as relevant (i.e., discussing the impact of the Swiss franc shock in an informative way) or not (e.g., just listing daily stock market winners or losers). We identify 429 relevant article-firm observations (note that one article can yield multiple article-firm observations and one event can be covered in multiple news outlets). We assign news articles published on non-trading days (e.g., Sundays) to the next trading day.

${ }^{23}$ For the purpose of this analysis, EPS_Revision only takes on positive values in the three-day event window and is set to ' 0 ' in the pre-event period. Moreover, out of the fully interacted model, the term Post_SNB is subsumed by the industry-day fixed effects, FXRisk_Disc by the firm fixed effects, New_Info is identical to the interaction term 
Post_SNB and New_Info are negative and significant. This finding suggests that the release of new information reduces information asymmetry—as one would expect. At the same time, Post_SNB $\times$ FXRisk_Disc remains significantly negative and similar in magnitude as in table 2 . Better past risk disclosures are related to lower bid-ask spreads. The triple interaction is positive and significant for EPS_Revision and Combined (insignificant for News). The positive coefficients indicate that when the amount of newly generated information increases, it substitutes for other, already existing information. The role of past risk disclosures diminishes, and the information gap becomes smaller and ultimately disappears. In that sense, historical annual report disclosures are used similarly to what Shroff et al. [2017] find for the effects of peer information on firms' cost of capital, but the effects are much more short-lived. ${ }^{24}$

\subsection{CHANGES IN DAILY STOCK PRICES AROUND SWISS FRANC SHOCK}

One of the biggest empirical threats for our analysis is that a significantly negative relation between FXRisk_Disc and spreads reflects a firm's exposure to currency risk and not necessarily the quality of past disclosures. In table 2, we control for this possibility by including variables such as the proportion of international sales, the correlation between firm returns and exchange rates, or contemporaneous stock returns. From a valuation perspective, risk exposure should be what matters most for stock prices around an exogenous shock to firm fundamentals (through its impact on firms' growth opportunities). Disclosure quality, if anything, has a limited effect on this relation via the cost-of-capital channel (e.g., Lambert et al. [2012], Goldstein and Yang [2017]).

Post_SNB $\times$ New_Info and the two-way interaction FXRisk_Disc $\times$ New_Info is identical to the three-way interaction Post_SNB $\times$ FXRisk_Disc $\times$ New Info.

${ }^{24}$ In additional analyses (not tabulated) we also control for the potentially confounding effects of firm-initiated new public disclosures within days $[0 ;+2]$ of the SNB announcement. We create binary indicators for the release of adhoc statements and press briefings (4 firms) and for a firm's participation in pre-scheduled investor events (46 firms). The inclusion of these indicators (interacted with Post_SNB) does not affect our main results and inferences. 
We test this argument in two ways. First, we graphically examine the stock price reaction around the SNB announcement conditional on a firm's risk disclosure quality. Figure 5 reports the results. The graph plots mean daily stock returns for firms with high-quality risk disclosures (i.e., FXRisk_Disc greater than the sample median) and a synthetic control group in the 90 trading days surrounding the event. The control group is constructed such that the differences in daily stock returns are minimized over the $[-70 ;-1]$ pre-event period (see discussion of figure 3 for details). We find no differential stock price reaction between the two matched groups after the currency shock, suggesting that FXRisk_Disc is uncorrelated to risk exposure.

Second, we directly estimate the relation between stock price, disclosure quality, and currency risk exposure. To do so, we estimate a variant of equation (1) with the natural logarithm of Stock Price as the dependent variable (for details and results see section B.4 in the online appendix). We find that our proxy for risk disclosure quality is not significantly related to share price. At the same time, the two measures for currency risk exposure (Int_Sales and Hist_Corr_EUR) exhibit a significantly negative correlation with share price. Combined with table 2 , the evidence suggests that disclosure quality affects information asymmetry—as predicted by theory—but that the effects are too small in the days after the Swiss franc shock to also create a price reaction. On the other hand, risk exposure has a first-order effect on prices, but not on information asymmetry. ${ }^{25}$

\section{Field Analysis of the Use of Past Risk Disclosures by Various Stakeholders}

We next discuss various stakeholders' use of historical financial statement information. Specifically, we surveyed (1) sell-side financial analysts, (2) credit officers at lending banks, and

\footnotetext{
${ }^{25}$ The lack of a price reaction to changes in information asymmetry might seem surprising in light of theoretical predictions. However, it seems feasible that the large cash-flow effects triggered by the Swiss franc shock overpower the more subtle reduction in the adverse selection component of cost of capital. In turn, we are left with a low power setting to test for the valuation effects through the cost-of-capital channel.
} 
(3) IR managers working at firms affected by the Swiss franc shock. The purpose of collecting this field data is to provide context for the informational role of past risk disclosures and validate the inferences drawn from the archival tests (e.g., Soltes [2014], Bernstein et al. [2016]).

\subsection{REACTION OF SELL-SIDE FINANCIAL ANALYSTS TO SWISS FRANC SHOCK}

Sell-side analysts are an important information intermediary between firms and investors, and they should be among the first to assess the impact of the currency shock on firms' future expected cash flows. We develop the survey after an extensive review of the related literature (Graham et al. [2005], Dichev et al. [2013], Nelson and Skinner [2013], Brown et al. [2015, 2016]), and pretest it with several academics and practitioners. The survey comprises 15 questions and then asks for some demographic information. When we administered the survey, we only briefly explained the general purpose of the study but did not mention the exact goal. This structure should prevent several well-known survey biases (e.g., Orne [1962]). Part C of the online appendix provides more details on the survey together with all the results not explicitly tabulated in the main body of the study. We cross-reference the respective survey questions (Q) when discussing the results.

Our pool of suitable survey subjects comprises all sell-side analysts covering at least one of the 151 sample firms during the event period. We receive 77 completed surveys, resulting in a response rate of $9.4 \%{ }^{26}$ The median analyst in our sample covers 10 to 15 firms from up to three industries. Firms domiciled in Switzerland make up about $25 \%$ of the average analyst portfolio. However, a quarter of the respondents exclusively cover Swiss firms in their research.

The Swiss franc shock caught financial analysts by surprise. Only $3 \%$ of the respondents anticipated the move by the SNB within the next three months and only 20\% within a year (Q2).

\footnotetext{
${ }^{26}$ The response rate is comparable to other surveys of executives (8.4\% in Graham et al. [2005]), chief financial officers (5.4\% in Dichev et al. [2013]), and financial analysts (10.9\% or 7.1\% in Brown et al. [2015, 2016]).
} 
This result corresponds with the archival evidence in figure 1, and points to the unpredictability of the event. The currency shock had a big impact on firm fundamentals. $85 \%$ of the respondents thought that almost all of the Swiss firms in their portfolios were impacted by the event (Q3), and in all cases the effect was expected to be negative (Q4). The Swiss franc shock recalibrated analysts' stance towards currency risk. Before the event, only 36\% considered a typical firm's currency risk exposure important information when forming earnings forecasts or stock recommendations $(\mathrm{Q} 1)$. This number soared to 52\% after the event (Q15).

The Swiss franc shock triggered a swift reaction from sell-side analysts. They reassessed the prospects of almost their entire portfolio within the first two days of the SNB announcement (Q5.1). For about $80 \%$ of the firms, the reassessment led to a material adjustment of the qualitative inputs $(40 \%)$ and/or quantitative inputs $(70 \%)$ in the valuation models that analysts use for their earnings forecasts and stock recommendations (Q5.2). The main drivers behind the rapid response were the increased information needs and, hence, demand from clients as well as the presumed exposure of the firm to the currency shock (Q6). Analysts continued to evaluate the impact of the Swiss franc shock after the initial response. More than $60 \%$ reviewed the prospects of their entire portfolio in more detail in the two to three weeks that followed (Q7). This time pattern nicely corresponds with the duration of the information gap that lasted for about 10 trading days (see table 3, panel B).

Table 4 lists the survey answers to the questions about the importance of various information sources for the assessment of the Swiss franc shock of a typical firm immediately after the SNB announcement (Q8) and within the next two to three weeks (Q9). We list the answers in decreasing order of importance. ${ }^{27}$ As panel A suggests, personal experience/industry knowledge and private

\footnotetext{
${ }^{27}$ We presented the answers in random order to the subjects to avoid any order bias (Nelson and Skinner [2013]).
} 
communication with firm management were considered extremely important. Existing annual reports or other financial filings rank third, not statistically different from private communication or ad hoc announcements by the firm, but more important than market sources, media coverage, or peer information. Thus, not only did analysts consult annual reports to gather additional insights on the economic consequences of the currency shock, but this resource also ranked highest in terms of publicly available information. Our result contrasts with the information sources that analysts use under "normal" circumstances. Brown et al. [2015] find that industry knowledge and private communication with management are always important (see their table 1). Yet, annual reports or other financial filings are less relevant and rank substantially lower. Panel B provides insights into the dynamics of the information processing by analysts. In the three weeks after the event, annual reports and other filings lose ground (albeit not statistically significant), while firms' private communication and ad hoc announcements gain importance. These answers are consistent with our analysis of the substitutive effects of new information in section 3.4.3.

Asked directly what they use financial statement information for (Q10), analysts provided the responses listed in table 5, panel A. The main purpose was to better contextualize and interpret the translational and transactional currency risk exposure of the firm and, to a lesser degree, assess the effectiveness of its hedging strategy. These goals nicely map into our FXRisk_Disc score. Thus, when searching the annual report for relevant disclosures, analysts likely considered items included in our empirical proxy. To further corroborate such a direct link, we closely inspect analyst reports released within 15 days of the SNB announcement. We search for (anecdotal) evidence that analysts were using information from historical annual reports when assessing the impact of the Swiss franc shock. We found multiple incidents in which analysts were either directly referencing annual reports as their data source or, indirectly, were using information and numbers 
contained in firms' annual reports (or, more to the point, in the sections that comprise the FXRisk_Disc score) for their analysis and computations (see part D of the online appendix).

Panel B of table 5 indicates that a firm's business complexity together with variation in the quality of past disclosures pose the main obstacles in assessing the consequences of the currency shock (Q12). About half of the respondents considered assessing the impact of the event more difficult for some firms than others (Q11). In terms of how analysts incorporated the new information into their valuation models, $75 \%$ responded that they have made quantitative input adjustments, while about $40 \%$ reconsidered the entire situation of the firm or adjusted the valuation parameters (Q14). In sum, the results from our sell-side analysts survey underscore the importance of historical (risk) disclosures during the advent of new information.

\subsection{REACTION OF LENDING BANKS TO SWISS FRANC SHOCK}

Lending banks represent another group of stakeholders affected by the Swiss franc shock, but banks typically enjoy privileged access and closer ties to their clients than investors or analysts (e.g., Rajan [1992], Agarwal and Hauswald [2010]). We conducted a series of in-depth structured interviews with senior credit officers and risk managers of the four largest commercial banks in Switzerland. ${ }^{28}$ The interviews lasted about an hour. In the first part, the bank representatives explained how they handled the events of January 15. In the second part, we guided them through a questionnaire similar in structure and length to the analyst/IR manager survey.

Within four weeks of the SNB announcement (one week for listed firms), all four banks had reviewed their relevant loan portfolio, and typically classified it into three risk categories: (i) borrowers heavily affected by the Swiss franc shock, (ii) borrowers without material

\footnotetext{
${ }^{28} \mathrm{We}$ conducted five interviews in total, as one of the banks divides its credit office into publicly listed and privately held clients, and we interviewed senior management at both divisions.
} 
consequences, and (iii) firms considered somewhere in between. The first group was small, and the consensus was that the Swiss franc shock might have been the tipping point, but not the cause of the financial problems for these firms. The second group was surprisingly large (up to $80 \%$ ) and consisted primarily of smaller, private clients with a strong domestic focus. The third group underwent a more detailed review in the months that followed.

Our interviews yielded the following insights. First, the main, and for non-listed firms only, information source in the days immediately after the SNB announcement were existing financial disclosures including annual reports submitted during the periodic loan review. Only in rare instances and for large (listed) clients did loan officers establish a direct communication with the borrower at this stage. Second, as time went by, banks replaced "hard" information from existing financial filings with "soft" information. Loan officers often engaged in personal exchanges with their clients to gather additional information on the impact of the currency shock. This behavior is comparable to that of sell-side analysts but stretched over a window of up to six months. Third, two banks indicated that they tightened their clients' reporting requirements and frequency as response to the event, suggesting that existing reporting practices were not informative enough. In sum, we conclude that the usefulness of past risk disclosures also extends to a loan setting.

\subsection{REACTION OF INVESTOR-RELATIONS MANAGERS TO SWISS FRANC SHOCK}

4.3.1. Survey Results. We survey IR managers at the affected firms to better understand the external communication needs after the Swiss franc shock and the role that existing financial statements might have played in this interaction. Our survey comprises 15 questions, and we pretest it with several academics and practitioners. Part E of the online appendix provides more details on the survey together with all the results not explicitly tabulated in the main body of the study. 
We sent the survey to IR representatives at 149 of the 151 sample firms. ${ }^{29}$ The response rate is $26.2 \%$ or 39 completed surveys. The respondent firms, on average, do not differ from nonrespondent firms in terms of the firm characteristics used in the archival tests. IR managers working at Swiss firms in January 2015 were surprised by the SNB proclamation. Only 5\% expected such a move within the next three months, 35\% within a year (Q2). $60 \%$ predicted a negative impact on future expected cash flows, only $8 \%$ foresaw a positive effect (Q3). In many cases, the firm's foreign currency exposure was always part of the communication with external stakeholders (Q1). While its role did not shift for firms that considered it an integral part of their communication strategy, firms that used to largely ignore this issue in the past put more emphasis on currency risks after the event (Q15).

Firms quickly reached out to corporate outsiders. $46 \%$ of IR departments communicated with investors, analysts, etc. on the day of the SNB announcement, 64\% within the first week (Q4). The interactions were both proactive and a reaction to outside demand (Q7). The main goals were to reassure investors, reduce uncertainty in the marketplace, build reputation, and promote trust in the firm's reporting strategy (Q11). Table 6, panel A, lists the answers to the question about the internal and external recipients (Q5). Financial analysts were the primary audience for information on the currency shock, followed by institutional investors, and management or internal departments. Communication with banks, retail investors, and the external audit firm rank significantly lower. This ordering is consistent with the answers in the analyst and bank surveys.

Panel B of table 6 presents the information sources used by the IR departments in preparation of the external communication (Q6). Consultation with key management is ranked highest, trailed by existing internal reports, and past annual reports or other financial filings. Only $3 \%$ of

\footnotetext{
${ }^{29}$ We could not identify valid email addresses of IR managers at two of the sample firms.
} 
respondents felt that past annual reports were not important. Next, we examine the use of diverse communication channels. Table 7, panel A, reports the answers. Private communication with analysts and investors were the preferred means of communication in the days immediately after the SNB announcement (Q8). Ad hoc disclosures and press releases were only rarely used. This result is consistent with the answers from sell-side analysts (see table 4, panel A), and suggests that sophisticated market participants were seeking and IR departments fulfilling the need for nonformalized ways of conveying information that goes beyond past disclosures. In the weeks that followed, communication at pre-scheduled events became more important (e.g., investor days or conference calls), but private communication retained its role as key information source (Q9).

Panel B of table 7 indicates reasons why firms did not pursue a more proactive communication strategy (Q10). No clear rank order emerges. 44\% of respondents indicated that upcoming regular financial filings (e.g., the imminent release of the 2014 annual report) or pre-scheduled events were important. Fears of disclosing proprietary data or setting a disclosure precedent did not receive much weight, even though Graham et al. [2005] list them as the two primary reasons limiting firms' voluntary disclosure behavior (see their table 12).

Corporate outsiders were eager to obtain information about the currency shock. IR managers reported that web traffic, emails, and phone calls were above normal levels relative to the release of the firm's most recent quarterly or annual earnings (Q12). Information about the firm's transactional and translational exposure, followed by the nature and extent of the hedging strategy, were in particularly high demand (Q13). Asked more directly, 26\% (67\%) of IR professionals believed that information in historical disclosures was extremely (at least somewhat) important to outside stakeholders when assessing the immediate consequences of the Swiss franc shock (Q14). 
4.3.2. Connecting Survey Results to Archival Analyses. In this section, we integrate answers from the IR survey into the empirical analysis to gain additional insights (see e.g., Graham et al. [2014, 2017]). Specifically, we examine whether firms' direct communication with investors immediately after the SNB announcement could subsume the relation between FXRisk_Disc and bid-ask spreads. We code up two survey responses: (i) We define First_Week as binary indicator for the 23 firms (out of 37 with identifying data available) that said they had started to communicate with external stakeholders (e.g., investors, financial analysts) within a week of the event (Q4). (ii) We define Private_Comm as binary indicator for the 25 firms that said they deemed private communication with analysts and investors in the two days immediately following the SNB announcement extremely important (Q8). We then introduce these variables as additional controls in equation (1) and interact them with Post_SNB.

Table 8 reports the results. We begin with an analysis of the full survey sample. ${ }^{30}$ To allow benchmarking, we first estimate the model without additional survey variables (column 1). Post_SNB $\times$ FXRisk_Disc has the predicted sign and is significant at the $10 \%$-level but is smaller in magnitude than in table 2. This finding suggests that the reduced sample is powerful enough to detect the stipulated relation. In column (2), we introduce First_Week as additional control. The coefficient is negative and significant, suggesting that firms that were quicker to start communicating with investors and analysts experience a reduction in information asymmetry —as one would expect. In column (3), we add Private_Comm, and its coefficient is significantly negative. Firms that put more emphasis on private communication immediately following the event seem to benefit from lower information asymmetry. Post_SNB $\times$ FXRisk_Disc remains

\footnotetext{
${ }^{30}$ The table reports coefficients from estimating model (5) in table 2 . The actual number of firms used in the estimation is smaller than 37 because we lose additional observations due to collinearity with fixed effects.
} 
largely unchanged by these two additional controls. Note that the coefficient magnitude is larger for the binary IR survey variables compared to FXRisk_Disc. But their economic magnitude is comparable if not smaller than the effect of past risk disclosures. ${ }^{31}$ When we interact the IR survey variables with FXRisk_Disc (and Post_SNB), we find a positive (but mainly insignificant) coefficient on the triple interaction (not tabulated). This finding suggests a substitutive relation between past risk disclosures and concurrent IR communication, similar to the evidence on analyst forecast revisions and news coverage in table 3, panel C.

In light of the small sample, we next conduct an outlier analysis and identify one influential observation. ${ }^{32}$ We eliminate this firm from the analysis and re-estimate the three models (columns 4-6). All the reported coefficients become larger in magnitude and more significant. Notably, Post_SNB $\times$ FXRisk_Disc is now comparable in size to the main results in table 2. In sum, the results from integrating the IR survey responses into the archival tests suggest that direct communication with external stakeholders likely acts as additional moderator for the relation between past risk disclosures and bid-ask spreads.

\section{Conclusion}

We use the Swiss franc shock as experimental setting to shed light on the information dynamics of historical accounting reports. In archival analyses, we find that firms with better past risk disclosures experience a substantially mitigated increase in information asymmetry following

${ }^{31}$ For instance, in column (3), a one standard deviation change in FXRisk_Disc is related to a reduction in bid-ask spreads of -0.065 while the same change in Private_Comm is related to a reduction in spreads of -0.044 . If we also transform FXRisk_Disc into a binary indicator (splitting by the median), the coefficient is -0.241 compared to -0.167 for Private_Comm (both significant at the $1 \%$-level).

${ }^{32}$ We re-estimate model (1) from table 2 after deleting, one-by-one, each of the 37 sample firms with IR survey data. We then compute a statistic in the spirit of a firm-level DFBETA for each iteration by comparing the mean Post_SNB $\times$ FXRisk_Disc coefficient from the 36 regressions dropping all but firm $i$ to the coefficient after dropping firm $i$. The single largest (absolute) DFBETA value is 2.25 ( $>$ than the typical cutoff value of 2), followed by 0.64 . 
the currency shock. The information gap in bid-ask spreads appears within 30 minutes of the event and persists for about two weeks. During this time, new information gradually substitutes for the information content of past disclosures. Surveying sell-side analysts, lending banks, and IR managers indicates that existing disclosures are key to evaluate the translational and transactional effects of the currency shock, and sometimes (e.g., for smaller, unlisted firms) are the only resource available at short notice. The results imply that risk disclosures continue to attenuate information asymmetry and the costs of adverse selection well beyond their initial publication date.

One implication of our study is that being transparent has benefits beyond simply providing useful information at the initial release date. The same disclosures might be relevant in the future as they provide contextual information in case the firm's information environment changes. The potential benefits of reduced uncertainty in posterior trading are highest for firms with more transparent disclosures. This insight is important as it points to reduced costs of adverse selection that could arise from selling shares in the future and shows that past disclosures are helpful in leveling the playing field between informed and uniformed investors. On a more fundamental level, our results highlight that managers should care about the long-term consequences of their disclosure decisions. Even if information appears irrelevant now, it might become useful later. Thus, preparers, regulators and practitioners should not only consider the current decision usefulness of a certain disclosure, but also whether this information could become relevant at some point if circumstances change. 


\section{REFERENCES}

ABADIE, A., A. DIAMOND, AND J. HAINMUELLER. "Synthetic Control Methods for Comparative Case Studies: Estimating the Effect of California's Tobacco Control Program." Journal of the American Statistical Association 105 (2010): 493-505.

ACEMOGLU, D., S. JOHNSON, A. KERMANI, J. KWAK, AND T. MITTON. "The Value of Connections in Turbulent Times: Evidence from the United States." Journal of Financial Economics 121 (2016): 368-91.

AGARWAL, S., AND R. HAUSWALD. "Distance and Private Information in Lending." Review of Financial Studies 23 (2010): 2757-88.

AMIHUD, Y. "Illiquidity and Stock Returns: Cross-Section and Time-Series Effects." Journal of Financial Markets 5 (2002): 31-56.

BALAKRISHNAN, K., M. BILLINGS, B. KELLY, AND A. LJUNGQVIST. "Shaping Liquidity: On the Causal Effects of Voluntary Disclosure.” Journal of Finance 69 (2014): 2237-78.

BANKER, R., S. DAS, AND C. OU. "Prior Financial Ratio Information and Differential Market Response to Regulatory Changes." Journal of Accounting, Auditing \& Finance 10 (1995): 699-717.

BEAVER, W. "The Information Content of Annual Earnings Announcements." Journal of Accounting Research 6 (1968): 67-92.

BEGLEY, T., A. PURNANANDAM, AND K. ZHENG. "The Strategic Underreporting of Bank Risk." The Review of Financial Studies 30 (2017): 3376-415.

BERNSTEIN, S., X. GIROUD, AND R. TOWNSEND. "The Impact of Venture Capital Monitoring." Journal of Finance 71 (2016): 1591-622.

BLACCONIERE, W., AND D. PATTEN. "Environmental Disclosures, Regulatory Costs, and Changes in Firm Value." Journal of Accounting and Economics 18 (1994): 357-77.

BLOOMBERG NEWS. "SNB Unexpectedly Gives up Cap on Franc, Lowers Deposit Rate." 2015. Available from http://www.bloomberg.com/news/articles/2015-01-15/snb-unexpectedly-gives-upcap-on-franc-lowers-deposit-rate.

BONETTI, P., C. CHO, AND G. MICHELON. "Environmental Disclosure and the Cost of Capital: Evidence from the Fukushima Nuclear Disaster." Working paper, University of Exeter, 2018.

BROWN, L., A. CALL, M. CLEMENT, AND N. SHARP. "Inside the "Black Box" of Sell-Side Financial Analysts." Journal of Accounting Research 53 (2015): 1-47.

BROWN, L., A. CALL, M. CLEMENT, AND N. SHARP. "The Activities of Buy-Side Analysts and the Determinants of Their Stock Recommendations." Journal of Accounting and Economics 62 (2016): 139-56.

BROWN, L., AND M. ROZEFF. "The Superiority of Analyst Forecasts as Measures of Expectations: Evidence from Earnings.” Journal of Finance 33 (1978): 1-16.

BROWN, S., S. HILlEGEIST, AND K. LO. "The Effect of Earnings Surprises on Information Asymmetry." Journal of Accounting and Economics 47 (2009): 208-25.

CAMPBELL, J., H. CHEN, D. DHALIWAL, H.-M. LU, AND L. STEELE. "The Information Content of Mandatory Risk Factor Disclosures in Corporate Filings." Review of Accounting Studies 19 (2014): 396-455.

CAVALLO, E., S. GALIANI, I. NOY, AND J. PANTANO. "Catastrophic Natural Disasters and Economic Growth." Review of Economics and Statistics 95 (2013): 1549-61.

CHAN, K., Y. CHUNG, AND H. JOHNSON. "The Intraday Behavior of Bid-Ask Spreads for NYSE Stocks and CBOE Options." Journal of Financial and Quantitative Analysis 30 (1995): 329-46.

CHOI, J., L. GALLO, R. HANN, AND H. KIM. "Does Management Guidance Help Resolve Uncertainty around Macroeconomic Announcement?" Working paper, University of Maryland, 2019.

CHORDIA, T., R. ROLL, AND A. SUBRAHMANYAM. "Commonality in Liquidity." Journal of Financial Economics 56 (2000): 3-28.

CHRISTENSEN, H., L. HAIL, AND C. LEUZ. "Mandatory IFRS Reporting and Changes in Enforcement." Journal of Accounting and Economics 56 (2013): 147-77. 
CHRISTENSEN, H., L. HAIL, AND C. LEUZ. "Capital-Market Effects of Securities Regulation: Prior Conditions, Implementation, and Enforcement.” The Review of Financial Studies 29 (2016): 2885924.

CLINCH, G., AND R. VERRECCHIA. "Voluntary Disclosure and the Cost of Capital." Australian Journal of Management 40 (2015): 201-23.

CUNY, C., AND S. DUBE. "Does Reporting Quality Moderate the Relation between Economic Changes and Changes in the Cost of Debt?" Working paper, New York University, 2019.

DASKE, H., L. HAIL, C. LEUZ, AND R. VERDI. "Mandatory IFRS Reporting around the World: Early Evidence on the Economic Consequences." Journal of Accounting Research 46 (2008): 1085-142.

DASKE, H., L. HAIL, C. LEUZ, AND R. VERDI. "Adopting a Label: Heterogeneity in the Economic Consequences around IAS/IFRS Adoptions." Journal of Accounting Research 51 (2013): 495-547.

DELOITTE. The Deloitte CFO Survey: A Chill Wind Blows Q4 2014 Results. Zurich, Switzerland, 2015.

DIAMOND, D., AND R. VERRECCHIA. "Disclosure, Liquidity, and the Cost of Capital." Journal of Finance 46 (1991): 1325-59.

DICHEV, I., J. GRAHAM, C. HARVEY, AND S. RAJGOPAL. "Earnings Quality: Evidence from the Field." Journal of Accounting and Economics 56 (2013): 1-33.

DOIDGE, C., G.A. KAROLYI, AND R. STULZ. "Why Are Foreign Firms Listed in the U.S. Worth More?" Journal of Financial Economics 71 (2004): 205-38.

DRAKE, M., D. ROULSTONE, AND J. THORNOCK. "The Usefulness of Historical Accounting Reports." Journal of Accounting and Economics 61 (2016): 448-64.

EFING, M., R. FAHLENBRACH, C. HERPFER, AND P. KRÜGER. "How Do Investors and Firms React to an Unexpected Currency Appreciation Shock?" Working paper, Swiss Finance Institute, 2020.

FRANCIS, J., D. NANDA, AND P. OLSSON. "Voluntary Disclosure, Earnings Quality, and Cost of Capital." Journal of Accounting Research 46 (2008): 53-99.

GOLDSTEIN, I., AND L. YANG. "Information Disclosure in Financial Markets." Annual Review of Financial Economics 9 (2017): 101-25.

GRAHAM, J., M. HANLON, T. SHEVLIN, AND N. SHROFF. "Incentives for Tax Planning and Avoidance: Evidence from the Field." The Accounting Review 89 (2014): 991-1023.

GRAHAM, J., M. HANLON, T. SHEVLIN, AND N. SHROFF. "Tax Rates and Corporate DecisionMaking." The Review of Financial Studies 30 (2017): 3128-75.

GRAHAM, J., C. HARVEY, AND S. RAJGOPAL. "The Economic Implications of Corporate Financial Reporting." Journal of Accounting and Economics 40 (2005): 3-73.

HEFLIN, F., AND D. WALLACE. "The BP Oil Spill: Shareholder Wealth Effects and Environmental Disclosures." Journal of Business Finance \& Accounting 44 (2017): 337-74.

HEINLE, M., AND K. SMITH. “A Theory of Risk Disclosure.” Review of Accounting Studies 22 (2017): 1459-91.

JORION, P. "How Informative Are Value-at-Risk Disclosures?" The Accounting Review 77 (2002): 91131.

KIM, O., AND R. VERRECCHIA. "Market Liquidity and Volume around Earnings Announcements." Journal of Accounting and Economics 17 (1994): 41-67.

KIM, O., AND R. VERRECCHIA. "Pre-Announcement and Event-Period Private Information." Journal of Accounting and Economics 24 (1997): 395-419.

LAMBERT, R., C. LEUZ, AND R. VERRECCHIA. "Information Asymmetry, Information Precision, and the Cost of Capital." Review of Finance 16 (2012): 1-29.

LANG, M., AND M. MAFFETT. "Transparency and Liquidity Uncertainty in Crisis Periods." Journal of Accounting and Economics 52 (2011): 101-25.

LANG, M., AND L. STICE-LAWRENCE. "Textual Analysis and International Financial Reporting: Large Sample Evidence." Journal of Accounting and Economics 60 (2015): 110-35.

LEE, C. "Earnings News and Small Traders: An Intraday Analysis." Journal of Accounting and Economics 15 (1992): 265-302. 
LEUZ, C., AND C. SCHRAND. "Disclosure and the Cost of Capital: Evidence from Firms' Responses to the Enron Shock." Working paper, NBER, 2009.

LEUZ, C., AND R. VERRECCHIA. "The Economic Consequences of Increased Disclosure." Journal of Accounting Research 38 (2000): 91-124.

LI, F. “Annual Report Readability, Current Earnings, and Earnings Persistence.” Journal of Accounting and Economics 45 (2008): 221-47.

LINSMEIER, T., D. THORNTON, M. VENKATACHALAM, AND M. WELKER. "The Effect of Mandated Market Risk Disclosures on Trading Volume Sensitivity to Interest Rate, Exchange Rate, and Commodity Price Movements." The Accounting Review 77 (2002): 343-77.

MCINISH, T., AND R. WOOD. "An Analysis of Intraday Patterns in Bid/Ask Spreads for NYSE Stocks." Journal of Finance 47 (1992): 753-64.

NELSON, M., AND D. SKINNER. "How Should We Think About Earnings Quality? A Discussion of 'Earnings Quality: Evidence from the Field'." Journal of Accounting and Economics 56 (2013): 34-41.

NG, J., T. RUSTICUS, AND R. VERDI. "Implications of Transaction Costs for the Post-Earnings Announcement Drift." Journal of Accounting Research 46 (2008): 661-96.

ORNE, M. "On the Social Psychology of the Psychological Experiment: With Particular Reference to Demand Characteristics and Their Implications." American Psychologist 17 (1962): 776-83.

RAJAN, R. "Insiders and Outsiders: The Choice between Informed and Arm's-Length Debt." Journal of Finance 47 (1992): 1367-400.

ROGERS, J., D. SKINNER, AND S. ZECHMAN. "Run EDGAR Run: SEC Dissemination in a HighFrequency World." Journal of Accounting Research 55 (2017): 459-505.

SHROFF, N., A. SUN, H. WHITE, AND W. ZHANG. "Voluntary Disclosure and Information Asymmetry: Evidence from the 2005 Securities Offering Reform." Journal of Accounting Research 51 (2013): 1299-345.

SHROFF, N., R. VERDI, AND B. YOST. "When Does the Peer Information Environment Matter?" Journal of Accounting and Economics 64 (2017): 183-214.

SNB. "Swiss National Bank Sets Minimum Exchange Rate at CHF 1.20 Per Euro." 2011. Available from http://www.snb.ch/en/mmr/reference/pre_20110906/source/pre_20110906.en.pdf.

SNB. "Swiss National Bank Introduces Negative Interest Rates.” 2014. Available from http://www.snb.ch/en/mmr/reference/pre_20141218/source/pre_20141218.en.pdf.

SNB. "Swiss National Bank Discontinues Minimum Exchange Rate and Lowers Interest Rate to -0.75\%." 2015. Available from http://www.snb.ch/en/mmr/reference/pre_20150115/source/pre 20150115.en.pdf.

SOLTES, E. "Incorporating Field Data into Archival Research." Journal of Accounting Research 52 (2014): 521-40.

VERRECCHIA, R. "Essays on Disclosure.” Journal of Accounting and Economics 32 (2001): 97-180. 


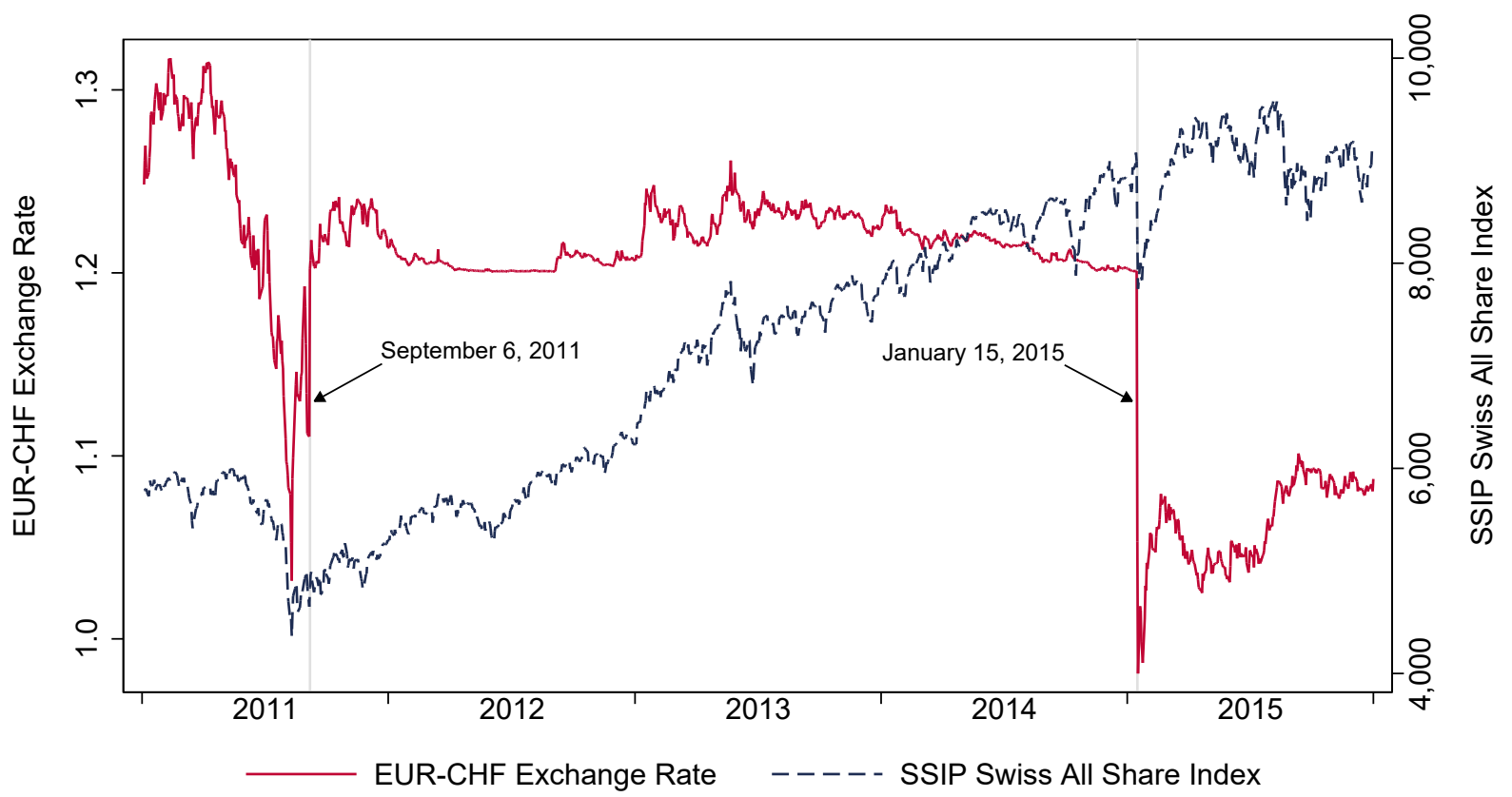

FIG. 1.-The figure plots the euro to Swiss franc (EUR-CHF) exchange rates (left-hand scale) and the Swiss All Share Index (symbol: SSIP; right-hand scale) over the years 2011 to 2015. The SSIP includes all shares of companies listed on the Swiss exchange SIX. Exchange rates and index values are from Datastream. The graph also indicates the dates when the Swiss National Bank (SNB) established the minimum exchange rate of CHF 1.20 per euro on September 6, 2011, and subsequently abandoned this lower threshold on January 15, 2015. 


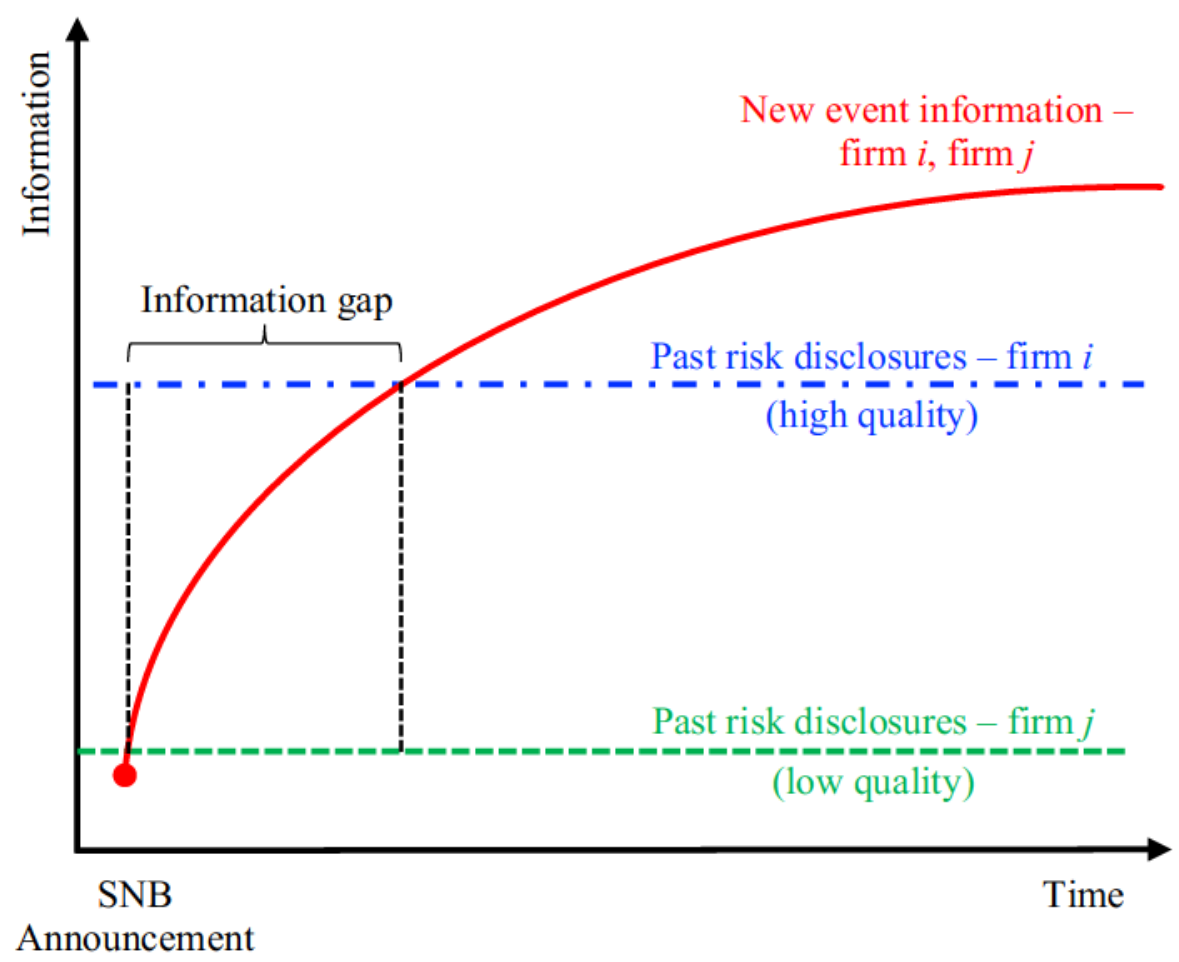

FIG. 2.- The figure provides a graphical depiction of the information dynamics around the Swiss franc shock. It shows that firm $i$ has better past risk disclosure quality than firm $j$ and that past risk disclosure quality remains constant over time. Following the SNB announcement, new event-specific information regarding firm $i$ or $j$ is generated (with a positive but decreasing slope). As a result of the two information sources (past and new), investors in firm $i$ benefit from a temporary information advantage relative to investors in firm $j$, which disappears when the new information curve crosses the past risk disclosures line for firm $i$. 


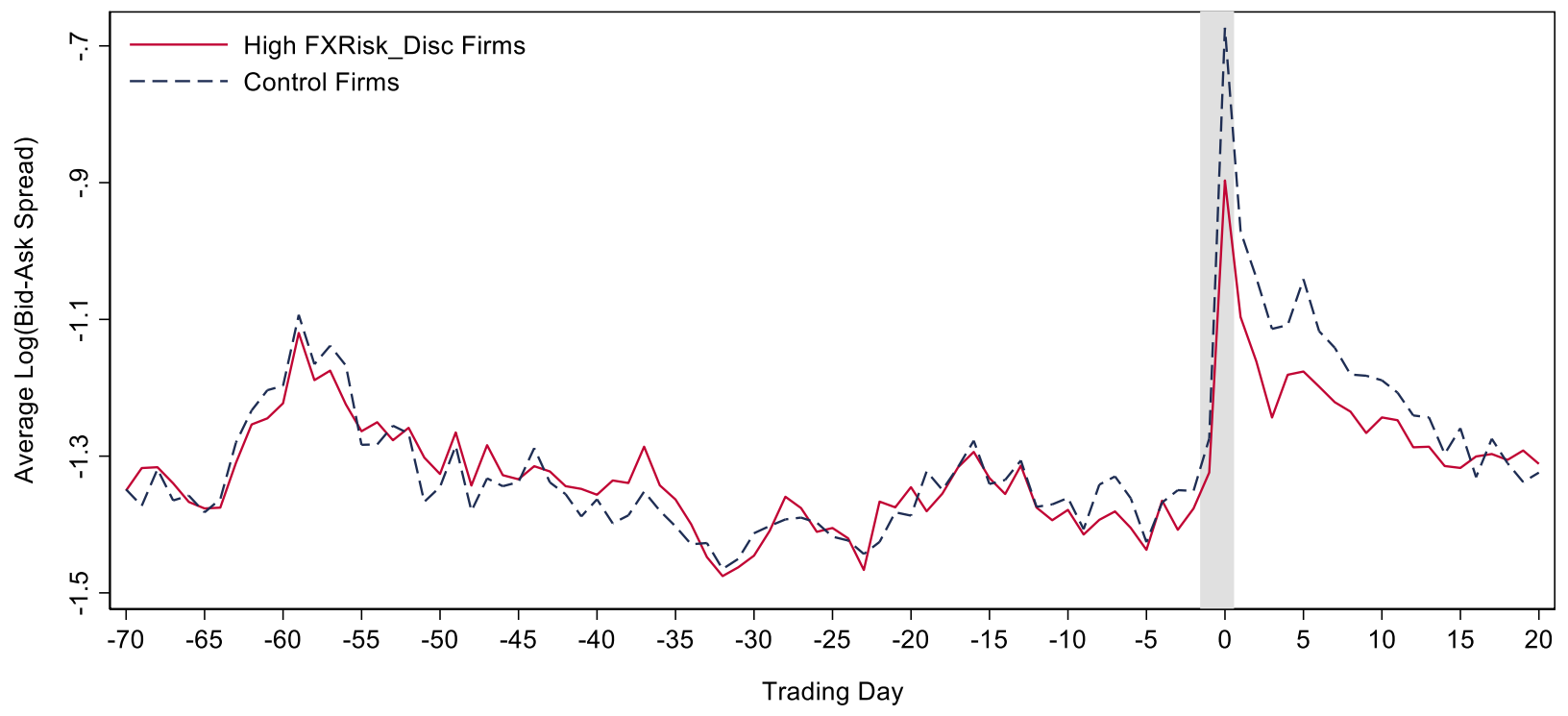

FIG. 3.-The figure examines changes in information asymmetry around the Swiss franc shock conditional on risk disclosure quality. It maps out bid-ask spreads in the 90 trading days (i.e., days $[-70 ;+20]$ ) surrounding the SNB announcement to discontinue the minimum EUR-CHF exchange rate on January 15, 2015 (day [0]). The sample comprises 151 firms listed on SIX. We plot the daily mean bid-ask spreads for the sample firms with an above median value of the foreign exchange risk disclosure score (FXRisk Disc) and a (synthetic) control group. For each treatment firm, we construct a synthetic control firm out of the benchmark pool (i.e., all firms with a risk disclosure score at or below the median) by using a weighting matrix that minimizes the differences in the outcome variables over the preevent period (days $[-70 ;-1]$ ). That is, we use a total of 70 daily bid-ask spreads for the matching. 


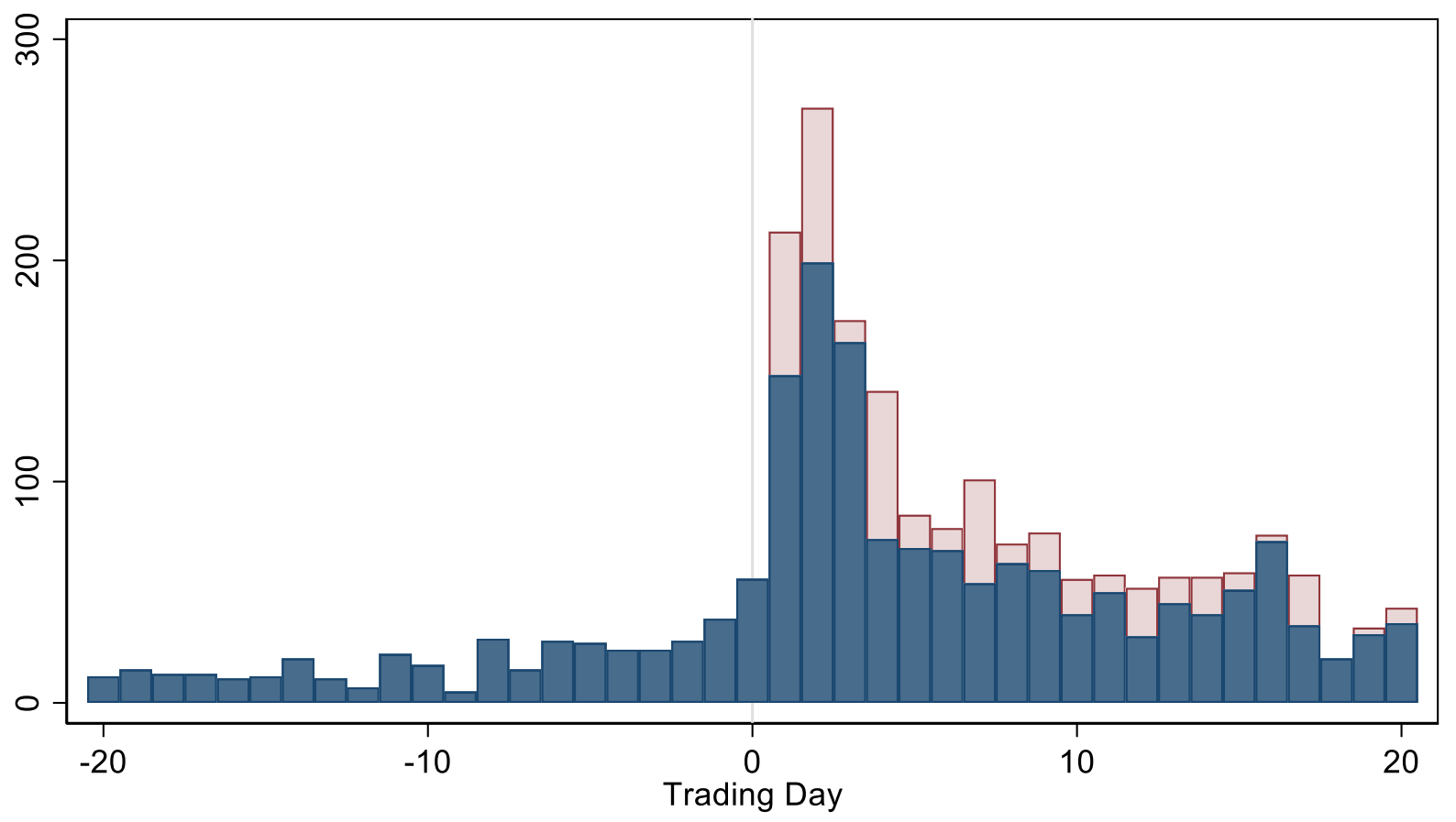

News $\square$ EPS Revision

FIG. 4.-The figure shows the arrival of new information after the SNB announcement. It plots the daily numbers of analyst earnings-per-share forecast revisions (EPS_Revision) and newspaper articles (News) in the 40 trading days (i.e., days $[-20 ;+20]$ ) surrounding the SNB announcement to discontinue the minimum EUR-CHF exchange rate (day [0]). The sample comprises 151 firms listed on SIX. We move EPS_Revisions released after 5:30 pm local time and News articles published on non-trading days to the next trading day. Because we only count newspaper articles covering the impact of the Swiss franc shock for specific sample firms, News is not defined in the pre-event period. 


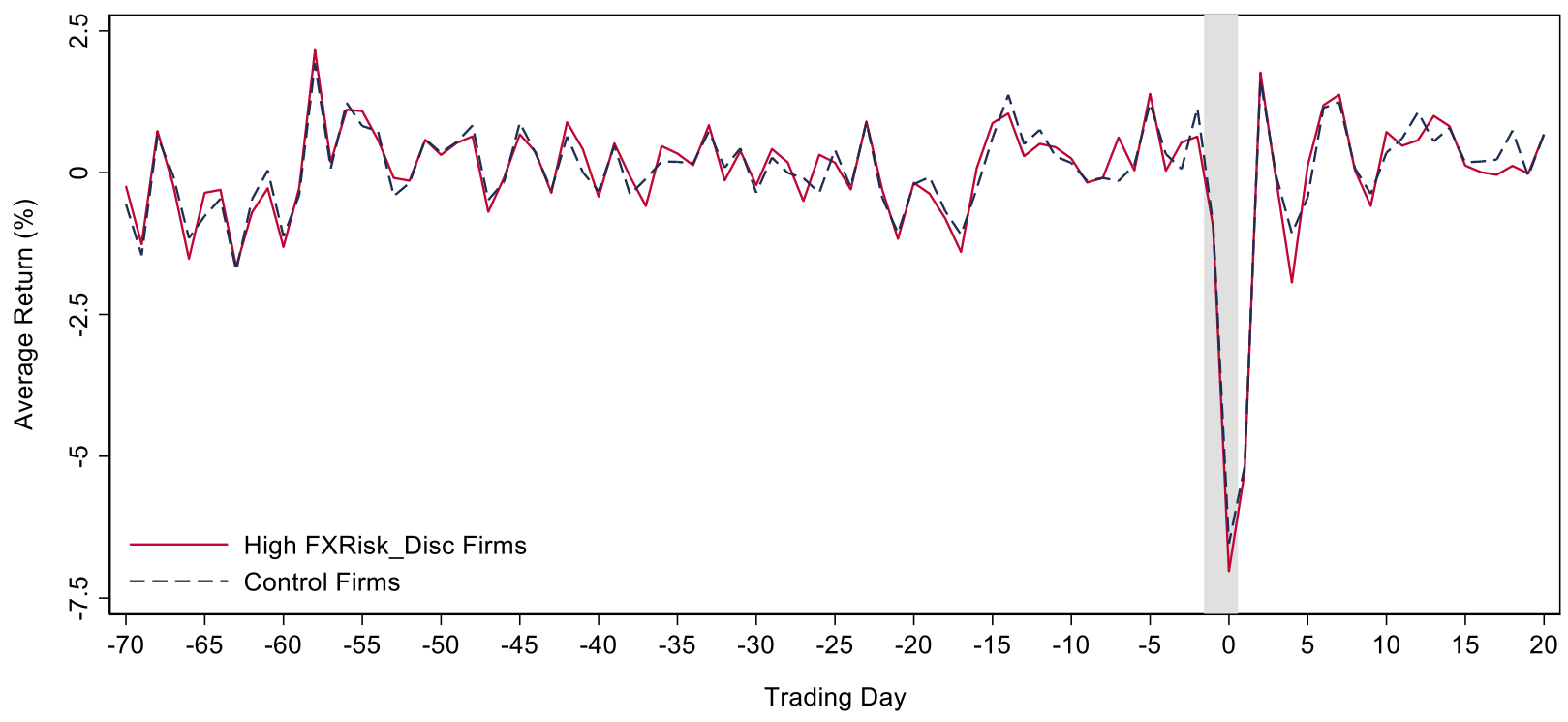

FIG. 5.-The figure examines market performance around the Swiss franc shock conditional on risk disclosure quality. It maps out daily stock returns in the 90 trading days (i.e., days $[-70 ;+20])$ surrounding the SNB announcement to discontinue the minimum EUR-CHF exchange rate (day [0]). The sample comprises 151 firms listed on SIX. We plot the daily mean stock returns for the sample firms with an above median value of the foreign exchange risk disclosure score (FXRisk_Disc) and a (synthetic) control group. We use the same matching algorithm as in figure 3 but with preevent daily returns as matching criteria. 
TABLE 1

Sample Selection and Descriptive Statistics for Archival Analysis

Panel A: Sample selection procedure

\begin{tabular}{lc}
\hline \hline Data Requirements & Number of Firms \\
\hline Members of the Swiss All Share Index as published by the Swiss exchange SIX & 237 \\
on 31.12.2014 (symbol: SSIP) & -63 \\
$-\quad$ thinly traded firms (i.e., firms with, on average, less than ten trades per day & \\
$\quad$ over the period October 2014 to April 2015) & -15 \\
$-\quad$ firms with narrow market depth (i.e., firms whose bid-ask spreads were not & \\
$\quad$ updated on more than 97.5\% of trading days over the period October 2014 & -8 \\
to April 2015) & 151 \\
$-\quad$ firms with missing data for variables used in the regression analysis & \\
Final sample & \\
\hline \hline
\end{tabular}

Panel B: Descriptive statistics for variables used in daily regression analyses (days: [-30 to +2$]$ )

\begin{tabular}{|c|c|c|c|c|c|c|c|}
\hline$(\mathrm{N}=4,949)$ & Mean & Std. Dev. & $\mathrm{P} 1$ & $\mathrm{P} 25$ & Median & P75 & P99 \\
\hline \multicolumn{8}{|l|}{ Dependent Variables: } \\
\hline Bid-Ask Spreadt & 0.482 & 1.107 & 0.050 & 0.144 & 0.264 & 0.471 & 3.774 \\
\hline Return Variabilityt & 0.528 & 0.660 & 0.052 & 0.235 & 0.351 & 0.549 & 3.300 \\
\hline \multicolumn{8}{|c|}{ Independent Variables: } \\
\hline Post_SNB $B_{t}$ & 0.091 & 0.288 & 0 & 0 & 0 & 0 & 1 \\
\hline FXRisk_Disc $c_{A R}$ & 4.027 & 1.425 & 1 & 3 & 4 & 5 & 7 \\
\hline Market Value $e_{t-1}$ & 8,870 & 32,488 & 26 & 444 & 1,263 & 4,569 & 232,508 \\
\hline Share Turnover $t_{t-1}$ & 0.230 & 0.772 & 0.002 & 0.042 & 0.114 & 0.242 & 1.967 \\
\hline Int_SalesAR & 0.654 & 0.386 & 0.000 & 0.285 & 0.876 & 0.980 & 1.000 \\
\hline Hist_Corr_EUR & 0.224 & 0.110 & -0.119 & 0.159 & 0.230 & 0.299 & 0.443 \\
\hline Total_Disc ${ }_{A R}$ & 3.665 & 0.747 & 2.037 & 3.180 & 3.632 & 4.173 & 5.102 \\
\hline Num_Analysts & 7.744 & 8.534 & 0 & 2 & 4 & 11 & 32 \\
\hline Free Float ${ }_{A R}$ & 0.663 & 0.249 & 0.110 & 0.450 & 0.690 & 0.890 & 1.000 \\
\hline Stock Return $_{t}$ & -0.256 & 2.737 & -11.083 & -0.894 & 0.000 & 0.831 & 5.500 \\
\hline
\end{tabular}




\section{TABLE 1-Continued}

The table presents details on the sample selection (panel A) and descriptive statistics for the variables used in the daily regression analyses (panel B). The final sample of 151 firms gives rise to 4,949 firm-day observations over the $[-30 ;+2]$ day period surrounding the SNB announcement to discontinue the minimum EUR-CHF exchange rate. We measure daily Bid-Ask Spreads as the mean of minute-by-minute intraday differences between bid and ask quotes (divided by the mid-point). We compute Return Variability as the standard deviation of stock returns over half-hourly intervals on a given trading day. Post_SNB is a binary indicator that takes on the value of ' 1 ' beginning on day $[t=0]$ of the SNB announcement (January 15,2015 ). To measure the quality of a firm's foreign exchange risk disclosures, we construct FXRisk Disc by scoring the following seven items as reported in the most recent annual report before the event (as indicated by the subscript $A R$ ): (i) revenues, (ii) assets, and (iii) costs and profits generated and held outside of Switzerland; (iv) the currency distribution of short-term monetary assets and liabilities; (v) the exposure to and (vi) the hedging strategy with regard to foreign currency risk; (vii) the sensitivity of net income or equity to changes in foreign exchange rates. We standardize the raw scores, ranging from 0 (worst) to 7 (best), for use in the regression analysis. See part A of the online appendix for details. Market Value is the number of shares outstanding times the stock price at the end of each trading day (in CHF million). We also compute the mean market value over the $[-30 ;-1]$ day period and mark the variable with a subscript (Market Value-30,-1; not tabulated). Share Turnover is the daily CHF trading volume divided by the market value at the end of the previous trading day. Int_Sales is the percentage of sales generated outside of Switzerland as shown in the most recent annual report. When exact data were missing (32 firms), we infer international sales from textual and other disclosures in the annual report. Hist_Corr_EUR is the Pearson correlation between a firm's weekly stock returns and the weekly changes in EUR-CHF exchange rates over the three years leading up to the day when the minimum exchange rate of CHF 1.20 per euro was established (September 6, 2011). When return data were missing over that period (4 firms), we use the correlation between weekly stock returns and USD-CHF exchange rates over the three years leading up to the event day $[t=0]$. Total Disc is a score, ranging from 1 (worst) to 6 (best), ranking the overall quality of a firm's annual report taken from the 2014 rating as published by the Institute for Banking and Finance of the University of Zurich. Num_Analysts is the number of analysts in I/B/E/S that cover the firm (i.e., provide a one-year-ahead earnings per share forecast) in the week before the SNB announcement. If analyst data were missing, we set the variable to zero. Free Float is the percentage of shares available to ordinary investors at the end of the most recent fiscal year (source: Datastream). We compute daily Stock Return as the natural logarithm of price at the end of trading over price at the end of the previous day. Stock price, spread, and volume data are from Bloomberg. For expositional purposes, we multiply bid-ask spreads, share turnover, return variability, and stock returns by 100 , expressing them in basis points. We do not winsorize or truncate the data. 
TABLE 2

Analysis of Daily Changes in Information Asymmetry around Swiss Franc Shock

\begin{tabular}{|c|c|c|c|c|c|c|}
\hline $\begin{array}{l}(\mathrm{N}=4,949) \\
\text { Days: }[-30 \text { to }+2]\end{array}$ & $\begin{array}{c}(1) \\
\log (\text { Bid-Ask } \\
\text { Spread })\end{array}$ & $\begin{array}{c}(2) \\
\log (\text { Bid-Ask } \\
\text { Spread })\end{array}$ & $\begin{array}{c}(3) \\
\log (\text { Bid-Ask } \\
\text { Spread })\end{array}$ & $\begin{array}{c}(4) \\
\log (\text { Bid-Ask } \\
\text { Spread })\end{array}$ & $\begin{array}{c}(5) \\
\log (\text { Bid-Ask } \\
\text { Spread })\end{array}$ & $\begin{array}{c}\text { (6) } \\
\text { Return } \\
\text { Variability }\end{array}$ \\
\hline \multicolumn{7}{|l|}{ Test Variables: } \\
\hline Post_SNB & $\begin{array}{l}0.367 * * * \\
(3.30)\end{array}$ & - & - & - & - & - \\
\hline Post_SNB $\times$ FXRisk_Disc & $\begin{array}{l}-0.103 * * * \\
(-5.36)\end{array}$ & $\begin{array}{l}-0.097 * * * \\
(-4.18)\end{array}$ & $\begin{array}{l}-0.105 * * * \\
(-4.76)\end{array}$ & $\begin{array}{l}-0.103 * * * \\
(-4.34)\end{array}$ & $\begin{array}{l}-0.104 * * * \\
(-4.17)\end{array}$ & $\begin{array}{l}-0.130 * * * \\
(-3.01)\end{array}$ \\
\hline \multicolumn{7}{|l|}{ Control Variables: } \\
\hline $\log \left(\right.$ Market Value $\left._{t-1}\right)$ & $\begin{array}{l}-0.243^{* * *} \\
(-3.94)\end{array}$ & $\begin{array}{l}-0.302 * * * \\
(-4.56)\end{array}$ & $\begin{array}{l}-0.286 * * * \\
(-4.89)\end{array}$ & $\begin{array}{l}-0.289 * * * \\
(-4.81)\end{array}$ & $\begin{array}{l}-0.300^{* * *} \\
(-4.31)\end{array}$ & $\begin{array}{c}-0.190 \\
(-1.43)\end{array}$ \\
\hline $\log \left(\right.$ Share Turnover $\left._{t-1}\right)$ & $\begin{array}{l}-0.028 * * * \\
(-3.00)\end{array}$ & $\begin{array}{l}-0.022^{* *} \\
(-2.52)\end{array}$ & $\begin{array}{l}-0.023^{* *} \\
(-2.59)\end{array}$ & $\begin{array}{l}-0.023^{* *} \\
(-2.58)\end{array}$ & $\begin{array}{l}-0.023^{* *} \\
(-2.54)\end{array}$ & $\begin{array}{l}0.018 * * \\
(2.45)\end{array}$ \\
\hline $\log \left(\right.$ Return Variability $\left._{t-1}\right)$ & $\begin{array}{l}0.061^{* *} \\
(2.49)\end{array}$ & $\begin{array}{l}0.091 * * * \\
(7.77)\end{array}$ & $\begin{array}{l}0.089 * * * \\
(7.48)\end{array}$ & $\begin{array}{l}0.089 * * * \\
(7.30)\end{array}$ & $\begin{array}{l}0.089 * * * \\
(7.47)\end{array}$ & $\begin{array}{l}0.038^{* *} \\
(2.07)\end{array}$ \\
\hline Post_SNB $\times \log ($ Market Value $-30,-1)$ & - & $\begin{array}{c}-0.024 \\
(-1.35)\end{array}$ & $\begin{array}{c}-0.024 \\
(-1.35)\end{array}$ & $\begin{array}{r}0.005 \\
(0.22)\end{array}$ & $\begin{array}{c}0.003 \\
(0.15)\end{array}$ & $\begin{array}{c}0.018 \\
(0.29)\end{array}$ \\
\hline Post_SNB $\times$ Int_Sales & - & - & - & $\begin{array}{c}0.019 \\
(0.26)\end{array}$ & $\begin{array}{c}-0.002 \\
(-0.03)\end{array}$ & - \\
\hline Post_SNB $\times$ Hist_Corr_EUR & - & - & - & $\begin{array}{l}-0.170 \\
(-0.71)\end{array}$ & $\begin{array}{l}-0.181 \\
(-0.73)\end{array}$ & - \\
\hline Post_SNB $\times$ Total_Disc & - & - & - & $\begin{array}{r}0.007 \\
(0.17)\end{array}$ & $\begin{array}{c}0.007 \\
(0.19)\end{array}$ & - \\
\hline Post_SNB $\times$ Num_Analysts & - & - & - & $\begin{array}{l}-0.005 * * \\
(-2.06)\end{array}$ & $\begin{array}{l}-0.005 * * \\
(-2.04)\end{array}$ & - \\
\hline Post_SNB $\times$ Free Float & - & - & - & $\begin{array}{l}-0.149 \\
(-1.27)\end{array}$ & $\begin{array}{l}-0.152 \\
(-1.42)\end{array}$ & - \\
\hline Stock Return $_{t}$ & - & - & - & - & $\begin{array}{l}-0.005^{* *} \\
(-2.71)\end{array}$ & - \\
\hline Post_SNB $\times$ Stock Return $t$ & - & - & - & - & $\begin{array}{l}-0.004 \\
(-1.30)\end{array}$ & - \\
\hline Fixed Effects & $\mathrm{F}$ & F \& D & F \& Ind-D & F \& Ind-D & F \& Ind-D & F \& D \\
\hline Adjusted $R^{2}$ (within) & 0.210 & 0.051 & 0.050 & 0.053 & 0.055 & 0.013 \\
\hline
\end{tabular}

The sample comprises 151 firms over the $[-30 ;+2]$ day period surrounding the SNB announcement to discontinue the minimum EUR-CHF exchange rate. The table reports OLS coefficient estimates and (in parentheses) $t$-statistics based on robust standard errors clustered by firm and day. We use daily Bid-Ask Spreads (Return Variability in column 6) as the dependent variable. Post_SNB is a binary indicator marking the event period. FXRisk_Disc is our score measuring the quality of a firm's foreign exchange risk disclosures. All variable details are in table 1. We include firm (F), day (D), or one-digit SIC industry-day (Ind-D) fixed effects in the regressions, but do not report the coefficients. If indicated, we use the natural log of the raw values and lag the variables by one day. ***, **, and * indicate statistical significance at the $1 \%, 5 \%$, and $10 \%$ levels (two-tailed). 
TABLE 3

Analysis of Information Dynamics around Swiss Franc Shock

Panel A: Intraday changes in bid-ask spreads

\begin{tabular}{|c|c|c|c|c|}
\hline \multirow{2}{*}{$\begin{array}{l}\text { Log(Bid-Ask Spread) } \\
\text { as Dependent Variable } \\
\text { Test Variables: }\end{array}$} & \multicolumn{2}{|c|}{$\begin{array}{c}(1) \\
\text { Days: }[-30 \text { to } 0]\end{array}$} & \multicolumn{2}{|c|}{$\begin{array}{c}(2) \\
\text { Day: [0] }\end{array}$} \\
\hline & & & & \\
\hline 09:00-09:30 Dummy & $-0.025^{*}$ & $(-1.74)$ & - & \\
\hline 09:00-09:30 Dummy $\times$ FXRisk_Disc & -0.005 & $(-0.22)$ & -0.022 & $(-1.01)$ \\
\hline 09:30-10:00 Dummy & 0.022 & $(1.50)$ & - & \\
\hline 09:30-10:00 Dummy $\times$ FXRisk_Disc & -0.037 & $(-1.60)$ & -0.045 & $(-1.50)$ \\
\hline 10:00-10:30 Dummy & $0.030 * *$ & $(1.99)$ & - & \\
\hline 10:00-10:30 Dummy $\times$ FXRisk Disc & 0.006 & $(0.45)$ & -0.003 & $(-0.14)$ \\
\hline 10:30-11:00 Dummy & $0.701 * * *$ & $(22.64)$ & - & \\
\hline 10:30-11:00 Dummy $\times$ FXRisk_Disc & -0.057 & $(-1.53)$ & $-0.079 *$ & $(-1.87)$ \\
\hline 11:00-11:30 Dummy & $0.902 * * *$ & $(26.87)$ & - & \\
\hline 11:00-11:30 Dummy $\times$ FXRisk Disc & $-0.122 * * *$ & $(-3.08)$ & $-0.159 * * *$ & $(-3.87)$ \\
\hline 11:30-12:00 Dummy & $0.753 * * *$ & (26.39) & - & \\
\hline 11:30-12:00 Dummy $\times$ FXRisk_Disc & $-0.074 * * *$ & $(-2.66)$ & $-0.107 * * *$ & $(-2.93)$ \\
\hline 12:00-12:30 Dummy & $0.836^{* * *}$ & $(24.87)$ & - & \\
\hline 12:00-12:30 Dummy $\times$ FXRisk Disc & $-0.146 * * *$ & $(-3.89)$ & $-0.164 * * *$ & $(-4.15)$ \\
\hline 12:30-13:00 Dummy & $0.911 * * *$ & (26.79) & - & \\
\hline 12:30-13:00 Dummy $\times$ FXRisk_Disc & $-0.206^{* * *}$ & $(-6.01)$ & $-0.197 * * *$ & $(-6.19)$ \\
\hline 13:00-13:30 Dummy & $0.730 * * *$ & (19.85) & - & \\
\hline 13:00-13:30 Dummy $\times$ FXRisk Disc & $-0.183 * * *$ & $(-4.96)$ & $-0.202 * * *$ & $(-4.46)$ \\
\hline 13:30-14:00 Dummy & $0.693 * * *$ & (20.09) & - & \\
\hline 13:30-14:00 Dummy $\times$ FXRisk_Disc & $-0.169 * * *$ & $(-5.13)$ & $-0.179 * * *$ & $(-4.75)$ \\
\hline 14:00-14:30 Dummy & $0.615^{* * *}$ & $(22.54)$ & - & \\
\hline 14:00-14:30 Dummy $\times$ FXRisk_Disc & $-0.137 * * *$ & $(-4.75)$ & $-0.142 * * *$ & $(-4.09)$ \\
\hline 14:30-15:00 Dummy & $0.486^{* * *}$ & $(22.63)$ & - & \\
\hline 14:30-15:00 Dummy $\times$ FXRisk_Disc & $-0.117 * * *$ & $(-4.96)$ & $-0.131 * * *$ & $(-4.26)$ \\
\hline 15:00-15:30 Dummy & $0.426^{* * *}$ & (18.78) & - & \\
\hline 15:00-15:30 Dummy $\times$ FXRisk_Disc & $-0.061 * *$ & $(-2.16)$ & $-0.072 * *$ & $(-2.13)$ \\
\hline 15:30-16:00 Dummy & $0.373 * * *$ & (16.59) & - & \\
\hline 15:30-16:00 Dummy $\times$ FXRisk_Disc & $-0.072 * * *$ & $(-2.80)$ & $-0.080 * *$ & $(-2.41)$ \\
\hline 16:00-16:30 Dummy & $0.328 * * *$ & (13.70) & - & \\
\hline 16:00-16:30 Dummy $\times$ FXRisk_Disc & $-0.096 * * *$ & $(-4.07)$ & $-0.133 * * *$ & $(-3.94)$ \\
\hline 16:30-17:00 Dummy & $0.386^{* * *}$ & $(15.05)$ & - & \\
\hline 16:30-17:00 Dummy $\times$ FXRisk_Disc & $-0.127 * * *$ & $(-5.01)$ & $-0.151 * * *$ & $(-4.09)$ \\
\hline 17:00-17:30 Dummy & $0.309 * * *$ & (14.14) & - & \\
\hline 17:00-17:30 Dummy $\times$ FXRisk_Disc & $-0.139 * * *$ & $(-6.22)$ & $-0.172 * * *$ & $(-4.99)$ \\
\hline Control Variables & \multicolumn{2}{|c|}{ Model (1) } & \multicolumn{2}{|c|}{ Model (1) } \\
\hline Fixed Effects & \multicolumn{2}{|c|}{$\mathrm{F} \& \mathrm{ToD}$} & \multicolumn{2}{|c|}{ ToD } \\
\hline Adjusted $R^{2}$ (within) / N & \multicolumn{2}{|c|}{$0.100 / 64,012$} & \multicolumn{2}{|c|}{$0.623 / 2,112$} \\
\hline
\end{tabular}

In panel $\mathrm{A}$, we use firm-intraday observations over the periods $[-30 ; 0]$ or $[0]$ for the analysis. The SNB announcement took place at 10:30 am on January 15, 2015 (day [0]). We compute intraday Bid-Ask Spreads as the means of minute-by-minute differences between bid and ask quotes (divided by the mid-point) over each 30-minute interval during trading hours (i.e., from 9 am to $5: 30 \mathrm{pm}$ ). For each interval we also construct a binary indicator that takes on the value of ' 1 ' during that time slot. For instance, the 11:30-12:00 Dummy represents the 30 minutes from 11:30 am to noon. We include the same control variables as in model (1) from table 2 but computed for each trading interval (and lagged by 17 trading intervals) as well as firm (F) and time-of-day (ToD) fixed effects in the regressions. The $t$-statistics (in parentheses) are based on robust standard errors clustered by firm and trading interval. 
TABLE 3-Continued

Panel B: Persistence of information gap in daily bid-ask spreads

\begin{tabular}{|c|c|c|c|c|c|c|}
\hline $\begin{array}{l}(\mathrm{N}=7,653) \\
\text { Days: }[-30 \text { to }+20]\end{array}$ & $\begin{array}{c}(1) \\
\log (\text { Bid-Ask } \\
\text { Spread })\end{array}$ & $\begin{array}{c}(2) \\
\log (\text { Bid-Ask } \\
\text { Spread })\end{array}$ & $\begin{array}{c}(3) \\
\log (\text { Bid-Ask } \\
\text { Spread })\end{array}$ & $\begin{array}{c}(4) \\
\log (\text { Bid-Ask } \\
\text { Spread })\end{array}$ & $\begin{array}{c}(5) \\
\log (\text { Bid-Ask } \\
\text { Spread })\end{array}$ & $\begin{array}{c}(6) \\
\text { Return } \\
\text { Variability }\end{array}$ \\
\hline \multicolumn{7}{|l|}{ Test Variables: } \\
\hline Post_SNB $0,+2$ & $\begin{array}{l}0.354 * * * \\
(3.22)\end{array}$ & - & - & - & - & - \\
\hline Post_SNB+3,+10 & $\begin{array}{l}0.157^{* * *} \\
(6.56)\end{array}$ & - & - & - & - & - \\
\hline Post_SNB+11,+20 & $\begin{array}{l}0.066^{* * * *} \\
(3.75)\end{array}$ & - & - & - & - & - \\
\hline Post_SNB $0,+2 \times F X R i s k \_D i s c$ & $\begin{array}{l}-0.102 * * * \\
(-5.14)\end{array}$ & $\begin{array}{l}-0.102 * * * \\
(-4.77)\end{array}$ & $\begin{array}{l}-0.109 * * * \\
(-5.35)\end{array}$ & $\begin{array}{l}-0.110 * * * \\
(-4.94)\end{array}$ & $\begin{array}{l}-0.110^{* * *} \\
(-4.92)\end{array}$ & $\begin{array}{l}-0.127^{* * * *} \\
(-3.45)\end{array}$ \\
\hline Post_SNB+3,+10$\times$ FXRisk_Disc & $\begin{array}{l}-0.048^{* *} \\
(-2.38)\end{array}$ & $\begin{array}{l}-0.046^{* *} \\
(-2.36)\end{array}$ & $\begin{array}{l}-0.053 * * * \\
(-2.97)\end{array}$ & $\begin{array}{l}-0.054 * * \\
(-2.64)\end{array}$ & $\begin{array}{l}-0.054^{* *} \\
(-2.64)\end{array}$ & $\begin{array}{l}-0.017 \\
(-1.26)\end{array}$ \\
\hline Post_SNB+11,+20 $\times$ FXRisk_Disc & $\begin{array}{c}0.004 \\
(0.19)\end{array}$ & $\begin{array}{r}0.005 \\
(0.26)\end{array}$ & $\begin{array}{c}0.002 \\
(0.15)\end{array}$ & $\begin{array}{r}0.001 \\
(0.06)\end{array}$ & $\begin{array}{r}0.001 \\
(0.06)\end{array}$ & $\begin{array}{r}0.007 \\
(0.59)\end{array}$ \\
\hline Control Variables & Model (1) & Model (2) & Model (3) & Model (4) & Model (5) & Model (6) \\
\hline Fixed Effects & $\mathrm{F}$ & F \& D & F \& Ind-D & F \& Ind-D & F \& Ind-D & F \& D \\
\hline Adjusted $R^{2}$ (within) & 0.193 & 0.056 & 0.056 & 0.056 & 0.057 & 0.019 \\
\hline
\end{tabular}

In panel $\mathrm{B}$, we use daily observations over an extended $[-30 ;+20]$ day period surrounding the SNB announcement for the analysis. We break the lengthened event window into three non-overlapping sub-periods, namely $[0 ;+2],[+3 ;+10]$, and $[+11 ;+20]$ (as captured by the binary indicators $P o s t \_S N B_{t}$ ). For the control variables, we use a single Post_SNB indicator for the interaction terms, which we code as ' 1 ' for the entire event window. 
TABLE 3-Continued

Panel C: Substitutive effects between past risk disclosure quality and newly generated information

\begin{tabular}{|c|c|c|c|c|c|c|}
\hline $\begin{array}{l}(\mathrm{N}=4,949) \\
\text { Days: }[-30 \text { to }+2]\end{array}$ & $\begin{array}{c}(1) \\
\log (\text { Bid-Ask } \\
\text { Spread })\end{array}$ & $\begin{array}{c}(2) \\
\log (\text { Bid-Ask } \\
\text { Spread) }\end{array}$ & $\begin{array}{c}(3) \\
\log (\text { Bid-Ask } \\
\text { Spread) }\end{array}$ & $\begin{array}{c}(4) \\
\log (\text { Bid-Ask } \\
\text { Spread })\end{array}$ & $\begin{array}{c}(5) \\
\log (\text { Bid-Ask } \\
\text { Spread })\end{array}$ & $\begin{array}{c}(6) \\
\log (\text { Bid-Ask } \\
\text { Spread) }\end{array}$ \\
\hline New Information Variables (New_Info): & \multicolumn{2}{|c|}{$\log (1+$ EPS_Revision $)$} & \multicolumn{2}{|c|}{$\log (1+N e w s)$} & \multicolumn{2}{|c|}{$\log (1+$ Combined $)$} \\
\hline Test Variables: & & & & & & \\
\hline Post_SNB $\times$ FXRisk_Disc & $\begin{array}{l}-0.136^{* * *} \\
(-5.24)\end{array}$ & $\begin{array}{l}-0.134^{* * *} \\
(-5.13)\end{array}$ & $\begin{array}{l}-0.102 * * * \\
(-3.95)\end{array}$ & $\begin{array}{l}-0.103^{* * *} \\
(-3.81)\end{array}$ & $\begin{array}{l}-0.132 * * * \\
(-4.89)\end{array}$ & $\begin{array}{l}-0.130 * * * \\
(-4.78)\end{array}$ \\
\hline New Information Variables: & & & & & & \\
\hline Post_SNB $\times$ New_Info & $\begin{array}{l}-0.080 * * * \\
(-3.73)\end{array}$ & $\begin{array}{l}-0.079 * * * \\
(-4.06)\end{array}$ & $\begin{array}{l}-0.089 * * \\
(-2.60)\end{array}$ & $\begin{array}{l}-0.082 * * * \\
(-2.84)\end{array}$ & $\begin{array}{l}-0.092 * * * \\
(-5.07)\end{array}$ & $\begin{array}{l}-0.090^{* * * *} \\
(-5.63)\end{array}$ \\
\hline Post_SNB $\times$ FXRisk_Disc $\times$ New_Info & $\begin{array}{l}0.090^{* * *} \\
(3.08)\end{array}$ & $\begin{array}{l}0.084^{* * *} \\
(3.14)\end{array}$ & $\begin{array}{c}0.020 \\
(0.70)\end{array}$ & $\begin{array}{c}0.014 \\
(0.55)\end{array}$ & $\begin{array}{l}0.073^{* *} \\
(2.75)\end{array}$ & $\begin{array}{l}0.068^{* *} \\
(2.75)\end{array}$ \\
\hline Control Variables & Model (4) & Model (5) & Model (4) & Model (5) & Model (4) & Model (5) \\
\hline Fixed Effects & F \& Ind-D & F \& Ind-D & F \& Ind-D & F \& Ind-D & F \& Ind-D & F \& Ind-D \\
\hline Adjusted $R^{2}$ (within) & 0.056 & 0.058 & 0.054 & 0.056 & 0.056 & 0.058 \\
\hline
\end{tabular}

In panel $\mathrm{C}$, we use daily observations over the $[-30 ;+2]$ day period surrounding the SNB announcement for the analysis and include controls for newly generated information after the announcement. We measure new information (New_Info) in three ways: (i) EPS Revision is the daily number of analyst earningsper-share forecast revisions, (ii) News is the daily number of relevant newspaper articles, and (iii) Combined is the sum of the two. We move EPS_Revisions released after 5:30 pm local time and News articles published on non-trading days to the next trading day. We code the variables as positive integers over the event window $[0 ;+2]$ and set them to ' 0 ' otherwise. Log transformations are as indicated. Everything else across the three panels is the same as in the models indicated from table 2 , but we do not report the coefficients of the control variables and fixed effects. $* * *, * *$, and $*$ indicate statistical significance at the $1 \%$, $5 \%$, and $10 \%$ levels (two-tailed). 
TABLE 4

Survey of Sell-Side Analysts-Information Sources to Assess Economic Impact of Swiss Franc Shock

\section{Panel A: Short-term information sources}

Question 8: Immediately after the SNB announcement (i.e., within the first one or two days), how important were the following information sources for your assessment of the impact of the Swiss franc shock on a typical firm you followed? [7-point Likert scale: 1 to 7]

\begin{tabular}{|c|c|c|c|c|c|c|}
\hline & & & & & $\%$ of Respond & Vho Answered \\
\hline $\begin{array}{l}\text { Resp } \\
(\operatorname{Max}\end{array}$ & $\begin{array}{l}\text { nses } \\
\text { mum possible } \mathrm{N}=76 \text { ) }\end{array}$ & $\begin{array}{l}\text { Average } \\
\text { Rating }\end{array}$ & $\begin{array}{c}\text { Significantly } \\
\text { Different Than } \\
{[4=\text { Neutral] }}\end{array}$ & $\begin{array}{l}\text { Significantly } \\
\text { Different Than }\end{array}$ & $\begin{array}{c}\text { Extremely } \\
\text { Important } \\
{[6 \text { or } 7]}\end{array}$ & $\begin{array}{c}\text { Not at all } \\
\text { Important } \\
{[1 \text { or } 2]}\end{array}$ \\
\hline (1) & Personal experience including company/industry knowledge & 5.84 & *** & $3-9$ & 72.00 & 5.33 \\
\hline (2) & Private communication with management or investor relations & 5.61 & $* * *$ & $4-9$ & 68.42 & 10.53 \\
\hline (3) & Existing annual reports or other financial filings & 5.35 & $* * *$ & 1 and 5-9 & 57.33 & 9.33 \\
\hline (4) & Ad hoc information provided by the firm after the shock & 4.91 & $* * *$ & $1-3$ and $5-9$ & 48.68 & 18.42 \\
\hline$(5)$ & Commercial data providers (e.g., Bloomberg) & 4.00 & & $1-4$ and $7-9$ & 24.32 & 24.32 \\
\hline (6) & Stock price reactions & 3.97 & & $1-4$ and $8-9$ & 27.03 & 29.73 \\
\hline (7) & Peer firms (e.g., other firms' ad hoc information) & 3.42 & $* * *$ & $1-6$ and $8-9$ & 9.46 & 35.14 \\
\hline & Media coverage (e.g., press articles, TV features) & 2.76 & $* * *$ & $1-7$ and 9 & 5.41 & 54.05 \\
\hline (9) & Peer analysts (e.g., other analysts' forecasts revisions) & 2.14 & $* * *$ & $1-8$ & 0.00 & 67.12 \\
\hline
\end{tabular}

\section{Panel B: Medium-term information sources}

Question 9: Relative to the previous question, which information sources gained or lost importance in the two to three weeks following the SNB announcement for your assessment of the impact of the Swiss franc shock on a typical firm you followed? [3-point Likert scale: 1 to 3]

\begin{tabular}{|c|c|c|c|c|c|}
\hline \multirow[b]{2}{*}{$\begin{array}{l}\text { Responses } \\
\text { (Maximum possible } \mathrm{N}=76 \text { ) }\end{array}$} & \multirow{3}{*}{$\begin{array}{c}\begin{array}{c}\text { Average } \\
\text { Rating }\end{array} \\
2.37\end{array}$} & \multirow{2}{*}{$\begin{array}{c}\text { Significantly } \\
\text { Different Than } \\
\text { [2= Similar } \\
\text { Importance] }\end{array}$} & \multirow[b]{2}{*}{$\begin{array}{l}\text { Significantly } \\
\text { Different Than }\end{array}$} & \multicolumn{2}{|c|}{$\%$ of Respondents Who Answered } \\
\hline & & & & $\begin{array}{c}\text { Gained } \\
\text { Importance } \\
{[3]}\end{array}$ & $\begin{array}{c}\text { Lost } \\
\text { Importance } \\
{[1]}\end{array}$ \\
\hline (1) Private communication with management or investor relations & & *** & $3-9$ & 44.74 & 7.89 \\
\hline (2) Ad hoc information provided by the firm after the shock & 2.32 & $* * *$ & $3-9$ & 36.00 & 4.00 \\
\hline (3) Personal experience including company/industry knowledge & 2.13 & $* *$ & $1-2$ and $6-9$ & 22.67 & 9.33 \\
\hline (4) Stock price reactions & 2.03 & & $1-2$ and 9 & 24.00 & 21.33 \\
\hline (5) Peer firms (e.g., other firms' ad hoc information) & 1.97 & & $1-2$ and $8-9$ & 14.86 & 17.57 \\
\hline (6) Existing annual reports or other financial filings & 1.89 & & $1-3$ & 13.33 & 24.00 \\
\hline (7) Commercial data providers (e.g., Bloomberg) & 1.86 & $* *$ & $1-3$ & 6.76 & 20.27 \\
\hline (8) Peer analysts (e.g., other analysts' forecasts revisions) & 1.80 & $* * *$ & $1-5$ & 6.76 & 27.03 \\
\hline (9) Media coverage (e.g., press articles, TV features) & 1.76 & $* * *$ & $1-5$ & 8.11 & 32.43 \\
\hline
\end{tabular}

The sample comprises answers from a survey sent to sell-side analysts covering at least one firm listed on SIX during the SNB announcement. The table lists the average ratings (in decreasing order) of the responses to the survey question indicated in the table header as well as the percentages of responses in the two tails of the Likert scale. We also report the results from $t$-tests comparing the average rating of an item to the mid-point (where ***, **, and * stand for statistical significance at the $1 \%, 5 \%$, and $10 \%$ levels) and to the average ratings of all the other items. For the latter test, we report the item numbers that are statistically different at the $10 \%$ level, using Bonferroni-Holm adjusted $p$-values to correct for multiple pair-wise comparisons. 
TABLE 5

Survey of Sell-Side Analysts—Role of Financial Statements in Assessing Economic Impact of Swiss Franc Shock

\section{Panel A: Usefulness of existing annual report disclosures}

Question 10: How important were existing annual reports and other financial filings for your assessment of the following dimensions of a firm's currency exposure immediately after the Swiss franc shock (i.e., within the first one or two days)? [7-point Likert scale: 1 to 7]

\begin{tabular}{|c|c|c|c|c|c|c|}
\hline \multirow{2}{*}{\multicolumn{2}{|c|}{$\begin{array}{l}\text { Responses } \\
\text { (Maximum possible } \mathrm{N}=77 \text { ) }\end{array}$}} & \multirow{3}{*}{$\begin{array}{c}\begin{array}{c}\text { Average } \\
\text { Rating }\end{array} \\
5.84\end{array}$} & \multirow[b]{2}{*}{$\begin{array}{l}\text { Significantly } \\
\text { Different Than } \\
{[4=\text { Neutral }]}\end{array}$} & \multirow[b]{2}{*}{$\begin{array}{l}\text { Significantly } \\
\text { Different Than }\end{array}$} & \multicolumn{2}{|c|}{$\%$ of Respondents Who Answered } \\
\hline & & & & & $\begin{array}{c}\text { Extremely } \\
\text { Important } \\
{[6 \text { or } 7]}\end{array}$ & $\begin{array}{c}\text { Not at all } \\
\text { Important } \\
{[1 \text { or } 2]}\end{array}$ \\
\hline (1) & Translational exposure (e.g., arising from foreign subsidiaries) & & $* * *$ & $3-6$ & 73.33 & 6.67 \\
\hline$(2)$ & $\begin{array}{l}\text { Transactional exposure (e.g., currency mismatch between } \\
\text { revenues and costs) }\end{array}$ & 5.84 & $* * *$ & $3-6$ & 74.03 & 7.79 \\
\hline (3) & Hedging strategy & 4.80 & $* * *$ & $1-2$ and 4-6 & 36.84 & 13.16 \\
\hline (4) & One-time gains/losses (e.g., on cash holdings) & 4.36 & & $1-2$ & 36.84 & 25.00 \\
\hline & Operating and strategic responses (e.g., relocation decisions) & 3.93 & & $1-3$ & 26.67 & 32.00 \\
\hline & Sensitivity to indirect effects (e.g., GDP growth) & 3.89 & & $1-3$ & 19.74 & 28.95 \\
\hline
\end{tabular}

\section{Panel B: Firm-level heterogeneity in the usefulness of existing annual report disclosures}

Question 12: Why was it more difficult to assess the impact of the Swiss franc shock for some firms than for others? Due to differences in the ... [7-point Likert scale: 1 to 7]

\begin{tabular}{|c|c|c|c|c|c|}
\hline \multirow[b]{2}{*}{$\begin{array}{l}\text { Responses } \\
\text { (Maximum possible } \mathrm{N}=69 \text { ) }\end{array}$} & \multirow[b]{2}{*}{$\begin{array}{l}\text { Average } \\
\text { Rating }\end{array}$} & \multirow[b]{2}{*}{$\begin{array}{l}\text { Significantly } \\
\text { Different Than } \\
{[4=\text { Neutral }]}\end{array}$} & \multirow[b]{2}{*}{$\begin{array}{l}\text { Significantly } \\
\text { Different Than }\end{array}$} & \multicolumn{2}{|c|}{$\%$ of Respondents Who Answered } \\
\hline & & & & $\begin{array}{c}\text { Extremely } \\
\text { Important } \\
{[6 \text { or } 7]}\end{array}$ & $\begin{array}{c}\text { Not at all } \\
\text { Important } \\
{[1 \text { or } 2]}\end{array}$ \\
\hline (1) Complexity of firms' operations & 5.71 & $* * *$ & $3-4$ & 69.57 & 2.90 \\
\hline (2) Quality and availability of financial information & 5.54 & $* * *$ & $3-4$ & 62.32 & 5.80 \\
\hline (3) Uncertainty about strategic responses & 4.29 & $*$ & $1-2$ & 14.71 & 13.24 \\
\hline (4) Volatility of underlying business models & 4.26 & & $1-2$ & 23.53 & 13.24 \\
\hline
\end{tabular}

See the notes to table 4 . 
TABLE 6

Survey of IR Managers-Demand for and Sources of Information on Economic Impact of Swiss Franc Shock

\section{Panel A: Recipients of internal and external communication}

Question 5: How important were the following internal and external stakeholders in your decision to start communicating about the impact of the Swiss franc shock on your firm? [7-point Likert scale: 1 to 7$]$

\begin{tabular}{|c|c|c|c|c|c|}
\hline \multirow[b]{2}{*}{$\begin{array}{l}\text { Responses } \\
\text { (Maximum possible } \mathrm{N}=39 \text { ) }\end{array}$} & \multirow{3}{*}{$\begin{array}{c}\begin{array}{c}\text { Average } \\
\text { Rating }\end{array} \\
6.13\end{array}$} & \multirow[b]{2}{*}{$\begin{array}{c}\text { Significantly } \\
\text { Different Than } \\
{[4=\text { Neutral }]}\end{array}$} & \multirow[b]{2}{*}{$\begin{array}{l}\text { Significantly } \\
\text { Different Than }\end{array}$} & \multicolumn{2}{|c|}{$\%$ of Respondents Who Answered } \\
\hline & & & & $\begin{array}{c}\text { Extremely } \\
\text { Important } \\
{[6 \text { or } 7]}\end{array}$ & $\begin{array}{c}\text { Not at all } \\
\text { Important } \\
{[1 \text { or } 2]}\end{array}$ \\
\hline (1) Financial analysts (sell-side or buy-side) & & $* * *$ & $2-8$ & 74.36 & 0.00 \\
\hline (2) Institutional investors & 5.72 & $* * *$ & 1 and $4-8$ & 64.10 & 5.13 \\
\hline (3) Management or other internal departments (e.g., accounting) & 5.38 & $* * *$ & 1 and $5-8$ & 64.10 & 12.82 \\
\hline (4) Media and financial press & 5.08 & $* * *$ & $1-2$ and $5-8$ & 38.46 & 7.69 \\
\hline (5) Suppliers and customers & 3.95 & & $1-4$ and $7-8$ & 15.38 & 20.51 \\
\hline (6) Banks and other lending institutions & 3.79 & & $1-4$ & 12.82 & 25.64 \\
\hline (7) Retail investors & 3.38 & $* *$ & $1-4$ & 7.69 & 35.90 \\
\hline (8) External audit firm & 3.23 & $* * *$ & $1-5$ & 10.26 & 43.59 \\
\hline
\end{tabular}

\section{Panel B: Information sources for external communication}

Question 6: How important were the following information sources for your own preparation in advance of your communication with external stakeholders about the impact of the Swiss franc shock? [7-point Likert scale: 1 to 7]

\begin{tabular}{|c|c|c|c|c|c|}
\hline \multirow[b]{2}{*}{$\begin{array}{l}\text { Responses } \\
\text { (Maximum possible } \mathrm{N}=39 \text { ) }\end{array}$} & \multirow[b]{2}{*}{$\begin{array}{l}\text { Average } \\
\text { Rating }\end{array}$} & \multirow[b]{2}{*}{$\begin{array}{c}\text { Significantly } \\
\text { Different Than } \\
{[4=\text { Neutral] }}\end{array}$} & \multirow[b]{2}{*}{$\begin{array}{l}\text { Significantly } \\
\text { Different Than }\end{array}$} & \multicolumn{2}{|c|}{$\%$ of Respondents Who Answered } \\
\hline & & & & $\begin{array}{c}\text { Extremely } \\
\text { Important } \\
{[6 \text { or } 7]}\end{array}$ & $\begin{array}{c}\text { Not at all } \\
\text { Important } \\
{[1 \text { or } 2]}\end{array}$ \\
\hline (1) Consultation with key management (e.g., CFO) & 6.21 & $* * *$ & $2-6$ & 78.95 & 0.00 \\
\hline (2) Existing internal reports (other than financial statements) & 5.10 & $* * *$ & 1 and 4-6 & 51.28 & 10.26 \\
\hline (3) Existing annual reports or other financial filings & 4.85 & $* * *$ & 1 and 6 & 30.77 & 2.56 \\
\hline (4) Newly prepared ad hoc information and reports & 4.36 & & 1 and 6 & 35.90 & 25.64 \\
\hline (5) Feedback from analysts, the media, or the stock market & 4.26 & & $1-3$ and 6 & 28.21 & 12.82 \\
\hline (6) Consultation with outside experts, auditors, suppliers, etc. & 2.95 & $* * *$ & $1-5$ & 5.13 & 48.72 \\
\hline
\end{tabular}

The sample comprises answers from a survey sent to IR managers at firms listed on SIX that were potentially affected by the SNB announcement. The table lists the average ratings (in decreasing order) of the responses to the survey question indicated in the table header as well as the percentages of responses in the two tails of the Likert scale. We also report the results from $t$-tests comparing the average rating of an item to the mid-point (where ***, **, and * stand for statistical significance at the $1 \%, 5 \%$, and $10 \%$ levels) and to the average ratings of all the other items. For the latter test, we report the item numbers that are statistically different at the $10 \%$ level, using Bonferroni-Holm adjusted $p$-values to correct for multiple pair-wise comparisons. 
TABLE 7

Survey of IR Managers-Communication with External Stakeholders about Economic Impact of Swiss Franc Shock

\section{Panel A: Communication channels for initial response}

Question 8: Immediately after the SNB announcement (i.e., within the first one or two days), how important were the following channels for your firm's communication with external stakeholders about the impact of the Swiss franc shock? [7-point Likert scale: 1 to 7]

\begin{tabular}{|c|c|c|c|c|c|}
\hline \multirow[b]{2}{*}{$\begin{array}{l}\text { Responses } \\
\text { (Maximum possible } \mathrm{N}=39 \text { ) }\end{array}$} & \multirow{3}{*}{$\begin{array}{c}\begin{array}{c}\text { Average } \\
\text { Rating }\end{array} \\
5.31\end{array}$} & \multirow[b]{2}{*}{$\begin{array}{c}\text { Significantly } \\
\text { Different Than } \\
{[4=\text { Neutral] }}\end{array}$} & \multirow[b]{2}{*}{$\begin{array}{l}\text { Significantly } \\
\text { Different Than }\end{array}$} & \multicolumn{2}{|c|}{$\%$ of Respondents Who Answered } \\
\hline & & & & $\begin{array}{c}\text { Extremely } \\
\text { Important } \\
{[6 \text { or } 7]}\end{array}$ & $\begin{array}{c}\text { Not at all } \\
\text { Important } \\
{[1 \text { or } 2]}\end{array}$ \\
\hline (1) Private communication with analysts or investors & & $* * *$ & $2-4$ & 66.67 & 15.38 \\
\hline $\begin{array}{l}\text { (2) Presentations and Q\&A at already pre-scheduled events (e.g., } \\
\text { investor days or conference calls) }\end{array}$ & 4.41 & & 4 & 43.59 & 30.77 \\
\hline (3) Communication through media and financial press & 3.74 & & 1 and 4 & 17.95 & 30.77 \\
\hline (4) Ad hoc announcements or press releases & 2.36 & $* * *$ & $1-3$ & 5.13 & 64.10 \\
\hline
\end{tabular}

\section{Panel B: Firm-level heterogeneity in the initial response}

Question 10: What motives did prevent you from communicating more proactively with external stakeholders about the impact of the Swiss franc shock?

Please indicate the importance of the following motives. [7-point Likert scale: 1 to 7]

\begin{tabular}{|c|c|c|c|c|c|c|}
\hline \multirow{2}{*}{\multicolumn{2}{|c|}{$\begin{array}{l}\text { Responses } \\
\text { (Maximum possible } \mathrm{N}=36 \text { ) }\end{array}$}} & \multirow{3}{*}{$\begin{array}{c}\begin{array}{c}\text { Average } \\
\text { Rating }\end{array} \\
4.56\end{array}$} & \multirow[b]{2}{*}{$\begin{array}{c}\text { Significantly } \\
\text { Different Than } \\
\text { [4= Neutral] }\end{array}$} & \multirow[b]{2}{*}{$\begin{array}{l}\text { Significantly } \\
\text { Different Than }\end{array}$} & \multicolumn{2}{|c|}{$\%$ of Respondents Who Answered } \\
\hline & & & & & \multirow{2}{*}{$\begin{array}{c}\text { Extremely } \\
\text { Important } \\
\text { [6 or } 7]\end{array}$} & \multirow{2}{*}{$\begin{array}{l}\begin{array}{c}\text { Not at all } \\
\text { Important } \\
{[1 \text { or } 2]}\end{array} \\
20.59\end{array}$} \\
\hline$(1)$ & Upcoming regular financial filings or pre-scheduled events & & & $5-8$ & & \\
\hline (2) & Uncertainty about development of foreign exchange rates & 4.34 & & $5-8$ & 20.00 & 17.14 \\
\hline (3) & Limited impact of Swiss franc shock on firm & 4.25 & & 8 & 27.78 & 22.22 \\
\hline (4) & $\begin{array}{l}\text { Little perceived information needs (e.g., existing annual } \\
\text { reports or other financial filings provide accurate picture) }\end{array}$ & 4.15 & & 8 & 20.59 & 14.71 \\
\hline$(5)$ & Uncertainty about the effect of Swiss franc shock on firm & 3.57 & & $1-2$ and 8 & 22.86 & 40.00 \\
\hline (6) & Attracting unwanted scrutiny by investors, lending banks, etc. & 3.29 & $* *$ & $1-2$ & 17.65 & 44.12 \\
\hline (7) & $\begin{array}{l}\text { Fear of setting a disclosure precedent that might be difficult to } \\
\text { maintain or is inconsistent with current policies }\end{array}$ & 3.15 & $* * *$ & $1-3$ & 8.82 & 38.24 \\
\hline$(8)$ & Giving away company secrets or harming competitive position & 2.80 & $* * *$ & $1-5$ & 2.86 & 45.71 \\
\hline
\end{tabular}

See the notes to table 6 . 
TABLE 8

Connecting Answers from IR Survey to Empirical Analysis of Daily Bid-Ask Spreads

\begin{tabular}{|c|c|c|c|c|c|c|}
\hline \multirow[t]{2}{*}{ Days: $[-30$ to +2$]$} & $\begin{array}{c}(1) \\
\log (\text { Bid-Ask } \\
\text { Spread })\end{array}$ & $\begin{array}{c}(2) \\
\log (\text { Bid-Ask } \\
\text { Spread) }\end{array}$ & $\begin{array}{c}(3) \\
\log (\text { Bid-Ask } \\
\text { Spread })\end{array}$ & $\begin{array}{c}(4) \\
\log (\text { Bid-Ask } \\
\text { Spread })\end{array}$ & $\begin{array}{c}(5) \\
\log (\text { Bid-Ask } \\
\text { Spread })\end{array}$ & $\begin{array}{c}(6) \\
\log (\text { Bid-Ask } \\
\text { Spread })\end{array}$ \\
\hline & \multicolumn{3}{|c|}{$\begin{array}{c}\text { Full Survey Sample } \\
(\mathrm{N}=1,185 / 36 \text { Firms })\end{array}$} & \multicolumn{3}{|c|}{$\begin{array}{l}\text { After Deleting One Influential Observation } \\
\qquad(\mathrm{N}=1,119 / 34 \text { Firms })\end{array}$} \\
\hline \multicolumn{7}{|l|}{ Test Variables: } \\
\hline Post_SNB $\times$ FXRisk_Disc & $\begin{array}{l}-0.073^{*} \\
(-1.81)\end{array}$ & $\begin{array}{l}-0.100^{*} \\
(-1.99)\end{array}$ & $\begin{array}{l}-0.077^{*} \\
(-1.98)\end{array}$ & $\begin{array}{l}-0.098 * * * \\
(-2.96)\end{array}$ & $\begin{array}{l}-0.140 * * * \\
(-3.56)\end{array}$ & $\begin{array}{l}-0.121 * * * \\
(-4.73)\end{array}$ \\
\hline \multicolumn{7}{|l|}{ IR Survey Variables: } \\
\hline Post_SNB $\times$ First_Week & - & $\begin{array}{c}-0.149 * \\
(-1.96)\end{array}$ & - & - & $\begin{array}{l}-0.177^{* *} \\
(-2.50)\end{array}$ & - \\
\hline Post_SNB $\times$ Private_Comm & - & - & $\begin{array}{l}-0.093^{* *} \\
(-2.20)\end{array}$ & - & - & $\begin{array}{l}-0.145^{* * *} \\
(-4.10)\end{array}$ \\
\hline Control Variables & Model (5) & Model (5) & Model (5) & Model (5) & Model (5) & Model (5) \\
\hline Fixed Effects & F \& Ind-D & F \& Ind-D & F \& Ind-D & F \& Ind-D & F \& Ind-D & F \& Ind-D \\
\hline Adjusted $R^{2}$ (within) & 0.026 & 0.031 & 0.028 & 0.025 & 0.032 & 0.030 \\
\hline
\end{tabular}

The sample comprises 37 firms that participated in our survey of IR managers with sufficient data available (out of 39 that responded to the survey). In columns (1)-(3), we include all firms. In columns (4)-(6), we drop one influential observation based on an analysis of outliers. Across all columns, we lose additional observations due to collinearity with fixed effects. We exploit answers to two survey questions for the analysis: (i) First_Week is coded as ' 1 ' if a firm indicated that it had started to communicate with external stakeholders within a week of the SNB announcement and '0' otherwise (Q4; 23 firms). (ii) Private_Comm reflects the importance of a firm's private communication with analysts and investors in the two days immediately following the SNB announcement (Q8). We code the variable as ' 1 ' if a firm indicated that it deemed this private communication channel extremely important (categories 6 or 7 on a 7-point Likert scale; 25 firms) and ' 0 ' otherwise. Everything else is the same as in model (5) from table 2, but we do not report the coefficients of the control variables and fixed effects. $* * * * *$, and * indicate statistical significance at the $1 \%, 5 \%$, and $10 \%$ levels (two-tailed). 